ORNL/MD/LTR-208

\title{
MOX Average Power Test 30 GWd/MT PIE: Quick Look
}

\author{
R.N. Morris \\ C.A. Baldwin \\ S.A. Hodge \\ N.H. Packan
}

February 2001

Fissile Materials Disposition Program

Notice

This report was prepared as an account of work sponsored by an agency of the United States Government. Neither the United States Government nor any agency thereof, or any of their employees, makes any warranty, expressed or implied, or assumes any legal liability or responsibility for any third party's use or the results of such use, of any information, apparatus, product or process disclosed in this report, or represents that its use by such third party would not infringe privately owned rights. 
Revision History

\begin{tabular}{|c|l|l|}
\hline Revision number & Date Issued & \multicolumn{1}{|c|}{ Reason for revision } \\
\hline \hline 0 & February 2001 & First Issue \\
\hline
\end{tabular}


February 2001

Distribution

\section{MOX Average Power Test 30 GWd/MT PIE: Quick Look}

The enclosed document details the MOX Average Power Test initial PIE that was performed on the $30 \mathrm{GWd} / \mathrm{MT}$-withdrawal Capsules 3 and 10 under the guidance of the DOE-sponsored Fissile Materials Disposition Program (FMDP). This work was carried out at the Irradiated Fuels Examination Laboratory by the staff of the Metals and Ceramics Division of the Oak Ridge National Laboratory during the period from October 2000 though February 2001. A final report of the entire PIE for these capsules is scheduled for issue in September 2001.

This is a Level-2 document as defined in the Fissile Materials Disposition Program Light-Water Reactor Mixed-Oxide Fuel Irradiation Test Project Plan, ORNL/MD/LTR-78, Rev 2.

Sincerely,

Robert N. Morris

Fissile Materials Disposition Program

Enclosure

Distribution: See Section 7 of enclosure 


\title{
MOX Average Power Test 30 GWd/MT PIE: Quick Look
}

\author{
R.N. Morris \\ C.A. Baldwin \\ S.A. Hodge \\ N.H. Packan
}

February 2001

Oak Ridge National Laboratory 


\section{TABLE OF CONTENTS}

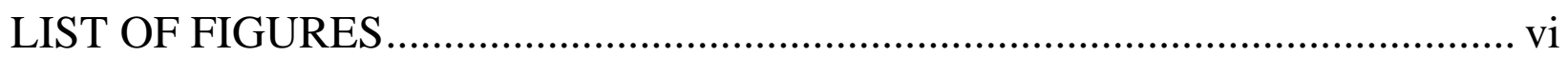

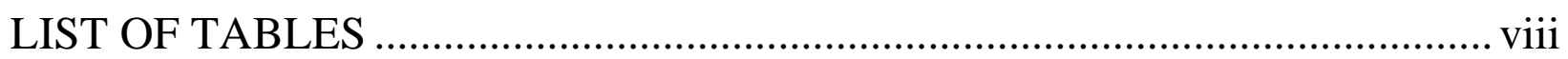

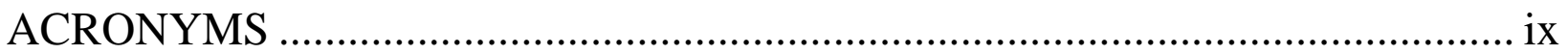

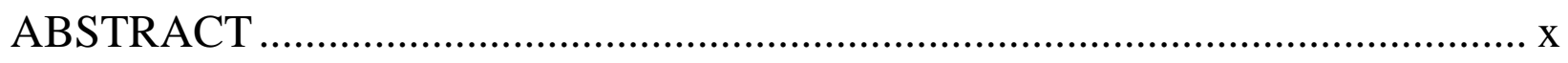

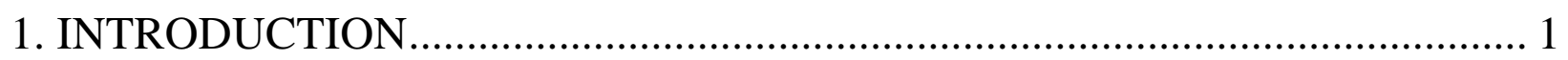

2. IRRADIATION HISTORY AND CARTS PREDICTIONS FOR CAPSULES 3

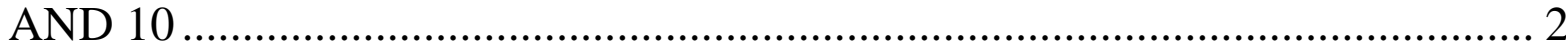

2.1 Irradiation History for Phases I and II ……………...................................................... 2

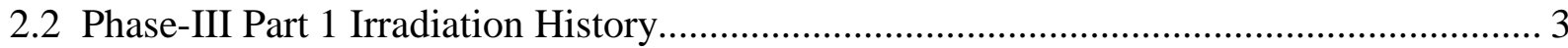

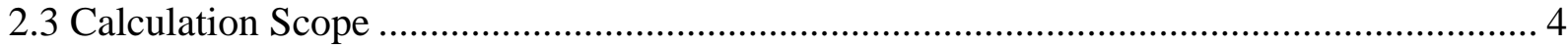

2.4 CARTS Results for Capsule Conditions During the Irradiation............................................. 5

2.4.1 Pellets with minimum initial gaps........................................................................... 5

2.4.2 Pellets with maximum initial gaps ........................................................................... 7

2.5 In-Reactor Conditions at the End of Phase III Part 1........................................................ 9

2.6 Predicted Conditions for the Capsules in the Hot Cell ........................................................ 9

2.7 Summary and Conclusions From the CARTS Predictions ................................................ 11

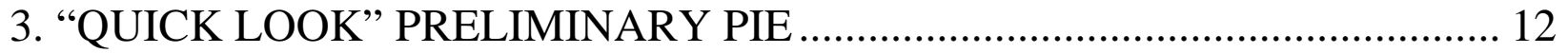

3.1 Capsule Photo Visual Inspection ............................................................................ 12

3.2 Capsule Temperature Measurements ............................................................................ 16

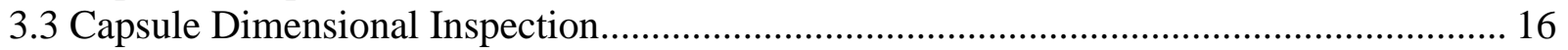

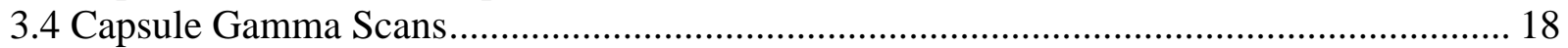

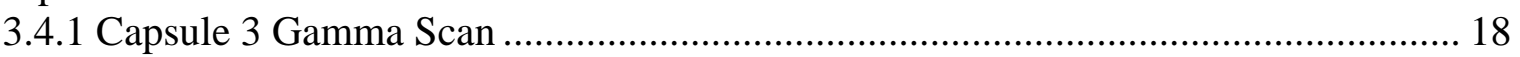

3.4.2 Capsule 10 Gamma Scan ................................................................................. 24

3.4.3 Gamma Scanner Data Collection Orientation......................................................... 29

3.5 Fission Gas Measurements ....................................................................................... 29

3.6 Fuel Pin Photo Visual Inspections .............................................................................. 32

3.7 Fuel Pin Dimensional Inspections ............................................................................. 34

4.0 CONCLUSIONS FROM PRELIMINARY PIE ............................................ 39

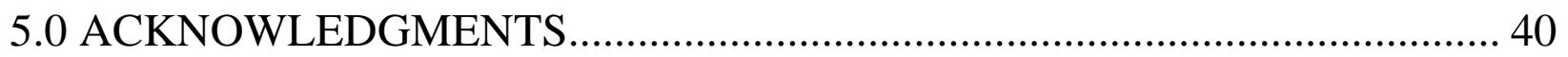

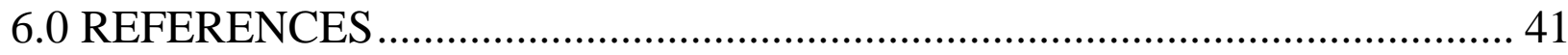

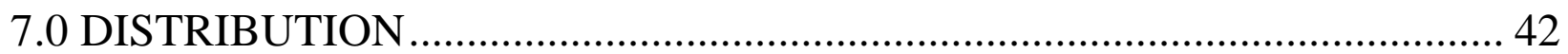




\section{LIST OF FIGURES}

Figure 2.1. CARTS predictions for Capsules 3 and 10 based upon minimum initial pellet-clad gaps.

Figure 2.2. CARTS predictions for Capsules 3 and 10 based upon maximum initial pellet-clad gaps.

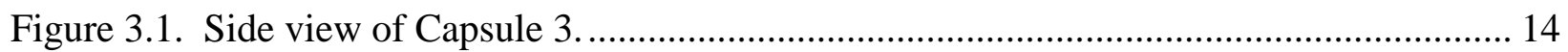

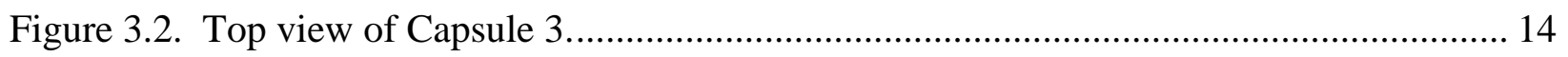

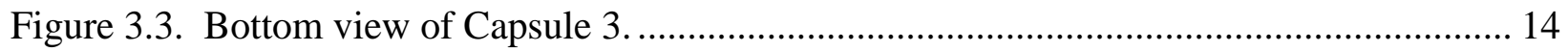

Figure 3.4. Side view of Capsule 10............................................................................... 15

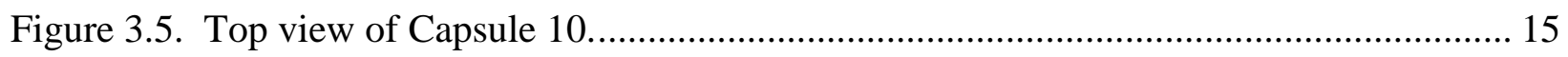

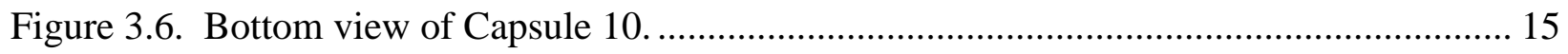

Figure 3.7. Free air temperature measurement on Capsule 3................................................. 17

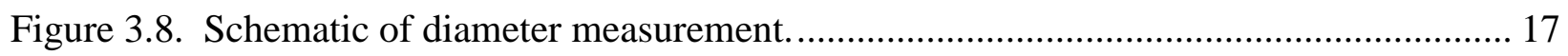

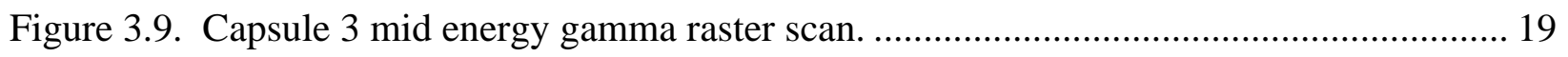

Figure 3.10. Capsule 3 high energy gamma raster scan. ........................................................... 21

Figure 3.11. Capsule 3 mid energy gamma line scan. ............................................................. 22

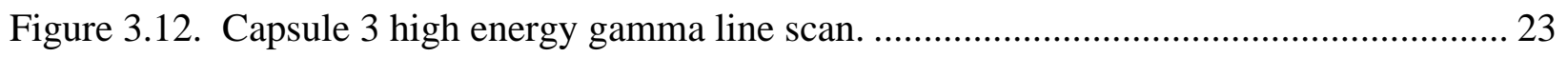

Figure 3.14. Capsule 10 high energy gamma raster scan. ......................................................... 26

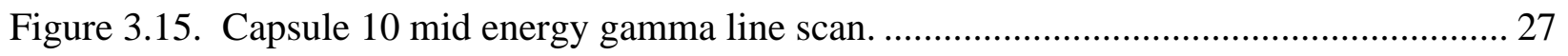

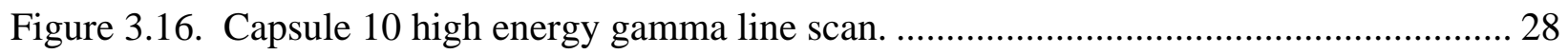

Figure 3.17 Orientation of the capsule and the gamma scanner collimator/detector.................... 29

Figure 3.18. Cross sectional view of the Fission Gas Pressure Measuring Apparatus. [Drill Schematic 3.wpg] .............................................................................................. 30 
Figure 3.19. Side view of Fuel Pin 6 (foreground). Shown in the background are the components of the capsule and the cut off portion of the fuel pin pedestal. The black rings near the ends are due to welding.

Figure 3.20. Top view of Fuel Pin 6. The lighting partially obscures the puncture hole. 32

Figure 3.21. Bottom view of Fuel Pin 6 33

Figure 3.22. Side view of Fuel Pin 13 (foreground). Shown in the background are the components of the capsule and the cut off portion of the fuel pin pedestal. The black rings near the ends are due to welding and the marks on the side of the pin are tubing lot information. 33

Figure 3.23. Top view of Fuel Pin 13. The lighting partially obscures the puncture hole. 34

Figure 3.24. Bottom view of Fuel Pin 13....... 34

Figure 3.25. Fuel pin measuring jig with Fuel Pin 6 in place. 35

Figure 3.26. Fuel pin measurement references. 36

Figure 3.27. Graph of Fuel Pin 6 diametrical measurements. 37

Figure 3.28. Graph of Fuel Pin 13 diametrical measurements. 38 


\section{LIST OF TABLES}

Table 2.1. Results of CARTS calculations for Capsules 3 and 10 just prior end of Phase III

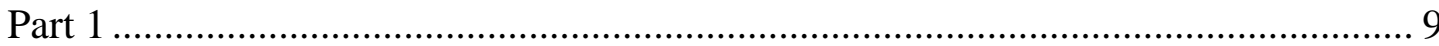

Table 2.2. CARTS predictions for Capsules 3 and 10 under hot cell conditions (mid-January 2001)

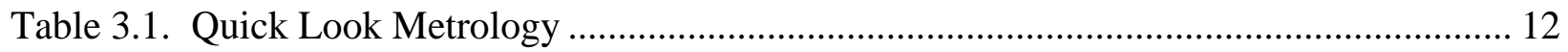

Table 3.2. Capsule and Fuel Pin Numbers................................................................... 13

Table 3.3. Capsule 3 and 10 Temperature Measurements ................................................. 16

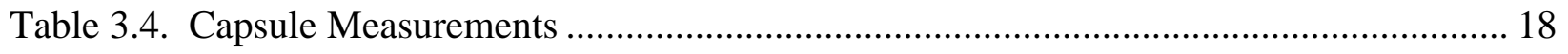

Table 3.5. Fission Gas Measurement ............................................................................ 31

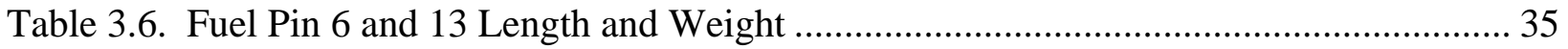

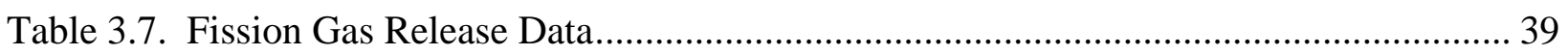




\section{ACRONYMS}

$\begin{array}{ll}\text { APT } & \text { Average Power Test } \\ \text { ATR } & \text { Advanced Test Reactor } \\ \text { BOL } & \text { Beginning of Life } \\ \text { CARTS } & \text { Capsule Assembly Response-Thermal Swelling (Code) } \\ \text { EFPD } & \text { Effective Full Power Days } \\ \text { FGPMA } & \text { Fission Gas Pressure Measuring Apparatus } \\ \text { FMDP } & \text { Fissile Materials Disposition Program } \\ \text { GWd/MT } & \text { Giga-Watt Days per Metric Ton } \\ \text { INEEL } & \text { Idaho National Engineering and Environmental Laboratory } \\ \text { LANL } & \text { Los Alamos National Laboratory } \\ \text { LHGR } & \text { Linear Heat Generation Rate } \\ \text { LWR } & \text { Light Water Reactor } \\ \text { MCNP } & \text { Monte Carlo Neutron Photon (Code) } \\ \text { Mils } & \text { 0.001 inches } \\ \text { MOX } & \text { Mixed Oxide } \\ \text { NRC } & \text { Nuclear Regulatory Commission } \\ \text { ORNL } & \text { Oak Ridge National Laboratory } \\ \text { PIE } & \text { Post Irradiation Examination } \\ \text { PPB } & \text { Parts Per Billion } \\ \text { PPM } & \text { Parts Per Million } \\ \text { PWR } & \text { Pressurized Water Reactor } \\ \text { RG } & \text { Reactor Grade } \\ \text { RMAL } & \text { Radioactive Materials Analysis Laboratory } \\ \text { TD } & \text { Theoretical Density } \\ \text { TIGR } & \text { Thermally Induced Gallium Removal } \\ \text { WG } & \text { Weapons Grade } \\ \end{array}$




\begin{abstract}
This report summarizes the early results of the post irradiation examination of the $30 \mathrm{GWd} / \mathrm{MT}$ MOX Average Power Test Capsules (numbers 3 and 10). The purpose of this preliminary examination is to document and monitor the progress of the MOX Average Power Test Irradiation. The capsules and their fuel pins were found to be in excellent condition. Measurement of the fission gas release fraction (about 1.50 to 2.26\%), preliminary fuel stack gamma scan measurements, and preliminary fuel pin diameter measurements indicate that the fuel is behaving as expected.
\end{abstract}




\section{INTRODUCTION}

This is the fifth report in a series of reports detailing the post irradiation examination (PIE) of the Fissile Materials Disposition Program (FMDP) Average Power MOX irradiation tests [Ref. 1]. These tests are investigating the use of weapons grade (WG) plutonium in mixed oxide (MOX) fuel for light-water reactors (LWR) to demonstrate that the substitution of weapons-derived plutonium for the reactor grade (RG) plutonium used in commercial MOX fuel does not negatively affect the performance of the fuel system and, thus, the commercial database is applicable. To meet this end, this test program was created to fabricate, assemble, and irradiate small test capsules containing weapons-derived MOX at expected fuel average power conditions, $6-10 \mathrm{~kW} / \mathrm{ft}$.

Simple, uninstrumented, drop-in capsules with local flux monitor wires were fabricated and placed in the Advanced Test Reactor (ATR) at Idaho National Engineering and Environmental Laboratory (INEEL). The average power test program comprises 13 capsules, 7 of which contain MOX fuel prepared without a gallium removal step, and 6 of which contain fuel prepared with a gallium removal step. The target irradiation goal is $50 \mathrm{GWd} / \mathrm{MT}$ for some capsules, but other capsules have been removed at 8,21 , and $30 \mathrm{GWd} / \mathrm{MT}$ for the purpose of monitoring the irradiation, and two capsules have been designated as unirradiated archives. The topic of this report is the early examination of the two capsules that have been withdrawn after irradiation to $30 \mathrm{GWd} / \mathrm{MT}$; four previous reports have dealt with the PIEs at $8 \mathrm{GWd} / \mathrm{MT}$ and $21 \mathrm{GWd} / \mathrm{MT}$ [Refs. 2-5].

As in the previous PIEs, the examination of the MOX capsules removed at $30 \mathrm{GWd} / \mathrm{MT}$ will be conducted in two steps. The first step is a "quick look", whose purpose is to determine the gross physical state of the capsule, cladding, and fuel. This first step is the topic of this report. The major goal of the quick look is to provide feedback to the irradiation group on issues that may impact the continued and safe operation of the capsules remaining in the ATR. This step also evaluates the usefulness of the current test apparatus and techniques for their role in the MOX irradiation task.

The second PIE step is a more detailed examination of the capsules for the purpose of collecting general cladding and fuel performance data for the FMDP program. The results of the second step PIE will be discussed in a final report for the $30 \mathrm{GWd} / \mathrm{MT}$ PIE scheduled for issue in September 2001.

The general PIE plan is detailed in Ref. 6. However, modifications to this plan may have taken place, especially in the areas of gallium analysis and clad testing, so the current FMDP PIE program manager should be consulted for details concerning the status of current PIE tasks. 


\section{IRRADIATION HISTORY AND CARTS PREDICTIONS FOR CAPSULES 3 AND 10}

The 30-GWd/MT postirradiation examination (PIE) is performed on Capsules 3 and 10, which occupied the two upper front positions within the test assembly during the Phase I, Phase II, and Phase III (Part 1) irradiations.

The pellet, fuel pin, and capsule behaviors during the as-run irradiations are predicted by application of the Capsule Assembly Response-Thermal Swelling (CARTS) code. In essence, CARTS determines the quasi-steady state coupled thermal/mechanical solutions at each point in a series of stepwise advances in burnup. In addition to calculating the interplays between fuel swelling and the temperatures and thermal expansions of the fuel and structures, the CARTS models predict the internal pressure associated with the fission gas released within the fuel pin. The latest descriptions of CARTS code operations are provided in Section 6.4 of Reference 7.

\subsection{Irradiation History for Phases I and II}

The irradiation period before withdrawal of Capsules 1 and 8 for the early PIE of the AveragePower Test is defined as Phase I. This phase, which extended from February 5 until September 13, 1998, comprises Advanced Test Reactor (ATR) Cycles 115C through 117B. The Inconel shield basket assembly (Model 1) was employed throughout. The linear heat generation rates (LHGRs) and accumulated burnups for Capsules 3 and 10 during the individual irradiation cycles are as follows:

$8.36 \mathrm{~kW} / \mathrm{ft}$ for 0.00 to $2.78 \mathrm{GWd} / \mathrm{MT}$ - Cycle 115C (48.4 EFPDs)
$7.79 \mathrm{~kW} / \mathrm{ft}$ for 2.78 to $3.45 \mathrm{GWd} / \mathrm{MT}$ - Cycle 116A (12.8 EFPDs)
$8.53 \mathrm{~kW} / \mathrm{ft}$ for 3.45 to $4.70 \mathrm{GWd} / \mathrm{MT}$ - Cycle 116B (22.2 EFPDs)
$7.53 \mathrm{~kW} / \mathrm{ft}$ for 4.70 to $5.41 \mathrm{GWd} / \mathrm{MT}$ - Cycle 117A (14.1 EFPDs)
$7.67 \mathrm{~kW} / \mathrm{ft}$ for 5.41 to $8.36 \mathrm{GWd} / \mathrm{MT}$ - Cycle 117B (57.4 EFPDs)
*EFPDs=Effective full-power days

These LHGRs are averages of the as-run values for Capsules 3 and 10, which occupied symmetric (left and right front-top) positions within the test assembly and experienced similar powers.

There were two brief unplanned ATR shutdowns during Cycle $115 \mathrm{C}$ and one during Cycle 116A. Thus, the test capsules were thermally cycled eight times during the five ATR operating cycles of the Phase-I irradiation. Capsules 1 and 8 were withdrawn at the end of Phase I and shipped to ORNL for PIE.

The Phase-II irradiation began on November 9, 1998, and continued until September 12, 1999, comprising ATR Cycles 118A through 120A. The Model-2 aluminum-shield basket assembly was employed throughout. The test assembly was loaded with seven capsules carried over from Phase I, plus two new fresh fuel capsules (6 and 12) to replace Capsules 1 and 8. Capsules 3 and 10 occupied the same left and right front-top positions during Phase II that they had occupied 
during Phase I.

The average LHGRs and accumulated burnups during the individual irradiation cycles are as follows:

$\begin{array}{lllllll}9.78 \mathrm{~kW} / \mathrm{ft} \text { for } & 8.36 & \text { to } & 10.16 \mathrm{GWd} / \mathrm{MT} & \text { - Cycle } 118 \mathrm{~A}(1) & \text { (27.4 EFPDs) } \\ 9.64 \mathrm{~kW} / \mathrm{ft} \text { for } & 10.16 & \text { to } & 11.54 \mathrm{GWd} / \mathrm{MT} & & \text { - Cycle } 118 \mathrm{~A}(2) & \text { (21.0 EFPDs) } \\ 9.57 \mathrm{~kW} / \mathrm{ft} \text { for } & 11.54 & \text { to } & 13.83 \mathrm{GWd} / \mathrm{MT} & \text { - Cycle } 118 \mathrm{~B} & \text { (36.4 EFPDs) } \\ 7.01 \mathrm{~kW} / \mathrm{ft} \text { for } & 13.83 & \text { to } & 14.62 \mathrm{GWd} / \mathrm{MT} & \text { - Cycle } 119 \mathrm{~A}(1) & \text { (19.2 EFPDs) } \\ 9.13 \mathrm{~kW} / \mathrm{ft} \text { for } & 14.62 & \text { to } & 14.75 \mathrm{GWd} / \mathrm{MT} & \text { - Cycle } 119 \mathrm{~A}(2) & \text { (2.5 EFPDs) } \\ 9.32 \mathrm{~kW} / \mathrm{ft} \text { for } & 14.75 & \text { to } & 16.01 \mathrm{GWd} / \mathrm{MT} & \text { - Cycle } 119 \mathrm{~A}(3) & \text { (22.9 EFPDs) } \\ 9.71 \mathrm{~kW} / \mathrm{ft} \text { for } & 16.01 & \text { to } & 18.24 \mathrm{GWd} / \mathrm{MT} & \text { - Cycle } 119 \mathrm{~B} & \text { (42.1 EFPDs) } \\ 7.33 \mathrm{~kW} / \mathrm{ft} \text { for } & 18.24 & \text { to } & 21.00 \mathrm{GWd} / \mathrm{MT} & \text { - Cycle } 120 \mathrm{~A} & \text { (56.2 EFPDs) }\end{array}$

With two brief unplanned shutdowns during Cycle 118B and one during Cycle 120A, the test capsules were thermally cycled 11 times during the eight operating cycles of Phase II.

Capsules 2 and 9 were withdrawn at the completion of Phase II and shipped to ORNL for PIE.

\subsection{Phase-III Part 1 Irradiation History}

The Phase-III irradiation began on October 9, 1999, with ATR Cycle 120C. Part 1 continued through Cycle 122C, which ended July 23, 2000. The Model-2 aluminum-shield basket assembly was employed throughout. The test assembly was loaded with five capsules carried over from Phases I and II, plus the two new capsules (6 and 12) that were introduced at the beginning of Phase II. Capsules 3 and 10 occupied the same left and right front-top positions during Phase III Part 1 that they had occupied during Phases I and II.

The test assembly loading pattern for Phase III Part 1 is illustrated in Figure 4 of the ATR Capsule Assembly Loading and Operation Schedule, ORNL/MD/LTR-91, Rev. 3. To complete the test assembly loading, the seven mixed uranium-plutonium oxide (MOX) test capsules were augmented by two solid stainless steel dummy capsules, which occupied the two front middle positions within the test assembly.

The CARTS code input for Capsules 3 and 10 during the individual cycles of Phase III Part 1 represents the following irradiation experience:

\begin{tabular}{|c|c|c|c|c|c|}
\hline $6.44 \mathrm{~kW} / \mathrm{ft}$ for & 21.00 & to & $22.47 \mathrm{GWd} / \mathrm{MT}$ & - Cycle 120C & (34.0 EFPDs) \\
\hline $5.05 \mathrm{~kW} / \mathrm{ft}$ for & 22.47 & to & $22.94 \mathrm{GWd} / \mathrm{MT}$ & - Cycle 121A & (14.0 EFPDs) \\
\hline $5.27 \mathrm{~kW} / \mathrm{ft}$ for & 22.94 & to & 23.65 GWd/MT & - Cycle 121B(1) & (19.5 EFPDs) \\
\hline $6.01 \mathrm{~kW} / \mathrm{ft}$ for & 23.65 & to & $\mathrm{GWd} / \mathrm{MT}$ & - Cycle 121B(2) & EFPDs) \\
\hline $5.57 \mathrm{~kW} / \mathrm{ft}$ for & 24.71 & to & $26.45 \mathrm{GWd} / \mathrm{MT}$ & - Cycle 121C & EFPDs) \\
\hline $5.46 \mathrm{~kW} / \mathrm{ft}$ for & 26.45 & to & $27.89 \mathrm{GWd} / \mathrm{MT}$ & - Cycle 122A & (40.9 EFPDs) \\
\hline $5.40 \mathrm{~kW} / \mathrm{ft}$ for & 27.89 & to & $29.64 \mathrm{GWd} / \mathrm{MT}$ & - Cycle 122C & (49.5 EFPDs) \\
\hline
\end{tabular}

With single unplanned shutdowns during Cycles 120C, 121B(2), 121C, and 122C, the test capsules were thermally cycled 11 times during the seven operating cycles of Phase III Part 1. 
The LHGRs and burnup accumulations for Phases I through III are taken from the as-run Monte Carlo N-Particle (MCNP) code results obtained at Idaho National Engineering and Environmental Laboratory (INEEL) at the conclusion of each ATR cycle. Uncertainties in these MCNP results are estimated to be $+/-2.5$ percent. Combining the Phase I, Phase II, and Phase III Part 1 experiences, Capsules 3 and 10 accumulated a total of 614.6 EFPDs (1.68 EFPY) and underwent 30 thermal cycles. The overall burnup-averaged LHGR for these capsules is $7.7 \mathrm{~kW} / \mathrm{ft}$. The highest LHGRs were $9.78 \mathrm{~kW} / \mathrm{ft}$ at the beginning and $9.71 \mathrm{~kW} / \mathrm{ft}$ near the end of Phase II. The integrated fast fluxes (E >1.0 MeV) are calculated as 1.22 E21 (fuel), 9.08 E20 (clad), and 7.8 E20 (steel) $\mathrm{n} / \mathrm{cm}^{2}$.

\subsection{Calculation Scope}

CARTS calculations for the 30-GWd/MT withdrawal capsules are based upon the actual burnup accumulations and average LHGRs experienced during ATR Cycles $115 \mathrm{C}$ through 122C, as described in the previous sections. Parameters varied are the initial pellet-to-clad and clad-tocapsule gaps (minimum versus maximum). The fuel performance models correspond to those utilized within the ESCORE code.

As noted previously, the highest LHGRs were imposed during Phase II. Since the highest calculated fuel centerline temperatures during this period remain far below the MOX fuel melting temperature, it is clear that fuel melting is not of concern in these test irradiations. Rather, the important concern, which arises from the small initial pellet-clad gaps, is the potential for excessive fuel swelling against the fuel pin clad. Accordingly, the CARTS analyses are primarily focused on the fuel swelling and densification models and the associated code input parameters

The CARTS calculations provide a predicted range for the postirradiation gaps as determined by the initial pellet-clad and clad-capsule gap widths. The considered pellet densification of 2.0 percent for use with the ESCORE-based fuel performance models is based upon the observations of the intermediate-withdrawal PIE as reported in the final report for the 21-GWd/MT withdrawal capsules (ORNL/MD/LTR-199). For consistency with the ESCORE fuel swelling model, the CARTS code input for these calculations provides that pellet densification be completed before burnup exceeds $10 \mathrm{GWd} / \mathrm{MT}$.

These CARTS calculations also represent the progressive expansion of the clad as noted in the intermediate-withdrawal PIE. This expansion is permanent, persisting after cooling has caused the pellet to shrink away from the inner clad surface. The extent is small, about 0.3 percent diameter increase projected for a burnup of $30 \mathrm{GWd} / \mathrm{MT}$.

The CARTS calculations were advanced in burnup steps of $0.01 \mathrm{GWd} / \mathrm{MT}$. Since the irradiation histories of Capsules 3 and 10 are nearly identical, the calculations were run for the averages of the as-run LHGRs. As explained previously, these two capsules were in symmetrical locations within the test assembly with respect to the ATR core. Their LHGRs were always in close agreement (maximum difference about 0.6 percent). Hence, the CARTS results discussed here are considered applicable to either capsule. 


\subsection{CARTS Results for Capsule Conditions During the Irradiation}

For the Average-Power Test, each capsule surrounds a fuel pin containing 15 MOX pellets. Each pellet has unique dimensions within the specified fabrication tolerances, so that a spectrum of initial pellet-to-clad gaps exists within each fuel pin. Results are reported for both the minimum and maximum initial gap widths.

Before discussing the conditions predicted for the capsule components in the hot cell, it is of interest to first consider the variations in pellet temperatures and diametral gaps as calculated for the period of reactor operation, with particular attention to the conditions at the end of Phase III Part 1, just prior to removal of the $30-\mathrm{GWd} / \mathrm{MT}$ capsules for PIE. It is important to note that the CARTS code predictions reported here are the first to be obtained for pellet densifications as high as 2.0 percent, and with representation of outward clad creep.

The safety analyses for the burnup extension beyond $30 \mathrm{GWd} / \mathrm{MT}$ employ assumed pellet densifications of either zero or 0.5 percent and neglect clad creep. This is appropriately conservative, and tends to cause pellet-clad contact (and the imposition of clad mechanical strain) to be predicted at lower burnups. With the greater pellet densifications inferred from the PIE results for the early- and intermediate-withdrawal capsules, the predicted initial pellet-clad contact is postponed to burnups beyond $30 \mathrm{GWd} / \mathrm{MT}$, as discussed in the following subsections.

\subsubsection{Pellets with minimum initial gaps}

Figure 2.1 illustrates the CARTS predictions of variations in pellet mean temperature, pellet-clad diametral gap, and clad mechanical strain as calculated for pellets with the largest initial diameter (minimum initial pellet-clad gap). In the interest of avoiding unnecessary clutter, the plot does not include spikes to zero power to mark the between-cycle reactor outages.

The clad mechanical strain is the result of any clad displacement that is forced by outward movement of the pellet surface, under the impetus of fuel thermal expansion and swelling. (For the current calculations, the pressure force is negligible.) For the pellets with minimum initial diametral gap (2.0 mils), Figure 2.1 shows that pellet-clad contact is not predicted to have occurred at any time during Phases I, II, or III. Consequently, the calculated clad mechanical strain remains zero throughout the irradiation.

With pellet densification of 2.0 percent completed before burnup reaches $10 \mathrm{GWd} / \mathrm{MT}$, the pellet diameter initially decreases during the irradiation, and is calculated to remain smaller than its initial value throughout both Phase I and Phase II. This in turn causes the predicted pellet-clad diametral gap to increase during Phase I and to remain greater than its initial value through the final burnup of 29.6 GWd/MT, as shown on Figure 2.1.

After densification has been completed, the calculated pellet-clad gap reaches its smallest value (0.78 mil) during Phase II, at the end of Cycle 119B (burnup 18.2 GWd/MT). Reduced LHGRs during the subsequent cycles lower the pellet temperature, and the concomitant reductions in thermal expansion tend to increase the pellet-clad gap. Continued pellet swelling counters this trend, however, as burnup increases. After several periods of temporary increase, the predicted 
ORNL 2000-1587 EFG
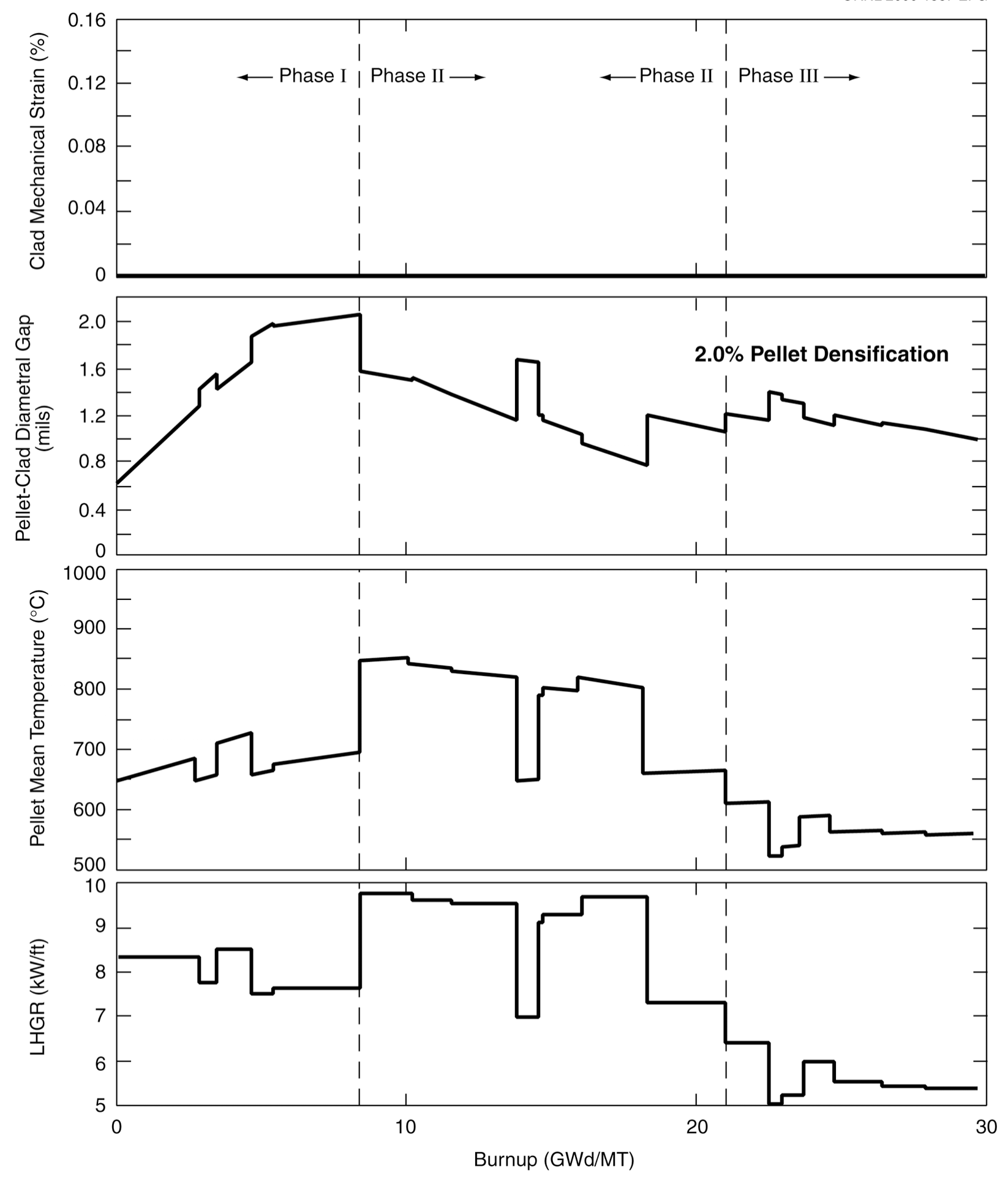

Figure 2.1. CARTS predictions for Capsules 3 and 10 based upon minimum initial pelletclad gaps. 
pellet-clad gap is again reduced, reaching 1.00 mil at the end of the irradiation.

The calculated pellet temperatures increase during periods while the LHGR remains constant during Phase I cycles. This reflects the decrease in gap thermal conductance that accompanies an increasing gap width. The opposite (temperatures decrease with shrinking gap under constant LHGR) occurs during the first few cycles of Phase II following completion of densification (at $10 \mathrm{GWd} / \mathrm{MT}$ ). Subsequently, the continuing buildup of fission gases in the gap monotonically lowers the gap conductance so that the calculated pellet temperatures increase during Phase III periods with constant LHGR.

No contact between the fuel pin and the capsule is predicted at any time during the irradiation.

\subsubsection{Pellets with maximum initial gaps}

Figure 2.2 illustrates the CARTS predictions for pellet mean temperature, pellet-clad diametral gap, and clad mechanical strain as calculated for pellets with the smallest initial diameters (maximum initial pellet-clad gap).

In general, the predicted pellet temperatures are higher for the maximum initial gap width cases. This follows from the lower effective thermal conductance associated with wider pellet-clad gaps. Figure 2.2 shows that the highest predicted pellet mean temperature $\left(967^{\circ} \mathrm{C}\right)$ occurs at the end of the first Phase-II cycle. The corresponding pellet centerline temperature is $1406^{\circ} \mathrm{C}$, which is more than $1200^{\circ} \mathrm{C}$ below the melting point of the MOX fuel. Thus although the calculated temperatures are higher for the pellets with maximum gaps, there is no concern for the possibility of fuel melting.

With pellet densification of 2.0 percent before burnup reaches $10 \mathrm{GWd} / \mathrm{MT}$, the calculated pellet diameter initially decreases, remaining smaller than its initial value throughout Phase I and the first cycle of Phase II. The associated pellet-clad diametral gap increases during Phase I and remains greater than its initial value until burnup reaches about $13 \mathrm{GWd} / \mathrm{MT}$, as shown on Figure 2.2. Pellet-clad contact is never predicted, and consequently, there is no clad mechanical strain.

The calculated pellet-clad gap reaches its smallest value (1.08 mil) during Phase II, at the end of Cycle 119B. Reduced LHGRs during the subsequent cycles lower the pellet temperature, and the thermal contractions tend to increase the pellet-clad gap. Continued pellet swelling counters this trend as burnup increases. After several temporary increases, the predicted pellet-clad gap is again reduced, reaching about 1.30 mil at the end of the irradiation. 
ORNL 2000-1591 EFG
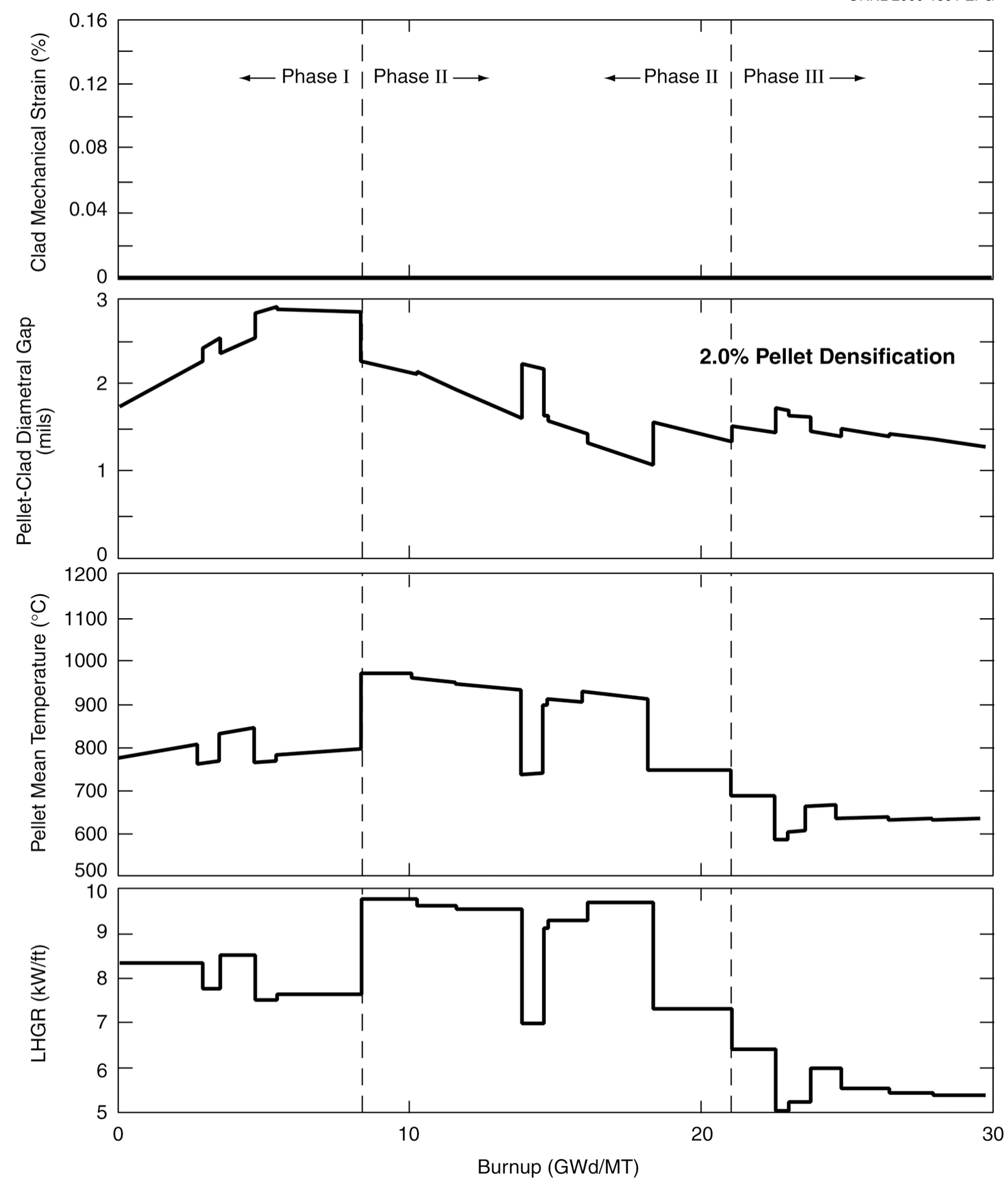

Figure 2.2. CARTS predictions for Capsules 3 and 10 based upon maximum initial pelletclad gaps. 


\subsection{In-Reactor Conditions at the End of Phase III Part 1}

Table 2.1 presents the results of the CARTS calculations for capsule conditions just prior to completion of the Phase-III Part 1 irradiation and withdrawal of Capsules 3 and 10 for PIE. Fuel burnup at this time is $29.6 \mathrm{GWd} / \mathrm{MT}$. As indicated in the last column of Table 2.1, neither of these calculations predicts pellet-clad contact at any time during the irradiation.

Table 2.1. Results of CARTS calculations for Capsules 3 and 10 just prior end of Phase III Part 1

\begin{tabular}{|c|c|c|c|c|c|c|c|}
\hline \multirow{2}{*}{$\begin{array}{l}\text { Initial } \\
\text { pellet- } \\
\text { clad gap }\end{array}$} & \multicolumn{4}{|c|}{ Temperatures ${ }^{\circ} \mathrm{C}$} & \multicolumn{2}{|c|}{ Diametral gap (mil) } & \multirow{2}{*}{$\begin{array}{l}\text { Pellet-clad } \\
\text { contact } \\
\text { during } \\
\text { irradiation }\end{array}$} \\
\hline & $\begin{array}{l}\text { Pellet } \\
\text { centerline }\end{array}$ & Pellet mean & Clad wall & Capsule wall & $\begin{array}{l}\text { Pellet-to- } \\
\text { clad }\end{array}$ & $\begin{array}{l}\text { Clad-to- } \\
\text { capsule }\end{array}$ & \\
\hline Minimum & 749 & 560 & 190 & 96.8 & 1.00 & 1.12 & Never \\
\hline Maximum & 833 & 632 & 224 & 96.7 & 1.30 & 2.06 & Never \\
\hline
\end{tabular}

Although the calculated capsule wall temperature is virtually independent of assumptions with respect to the initial pellet-clad gap width, the calculated clad temperature is lower for the pellets with minimum initial gaps. During reactor operation at the end of Phase III Part 1, the temperature $\left(190^{\circ} \mathrm{C}\right)$ of the clad surrounding these pellets is much higher than that (about $97^{\circ} \mathrm{C}$ ) of the capsule wall, where the temperature is controlled by forced convection to the coolant flow at the outer surface.

The predicted mean temperature for the pellets with minimum initial gaps is $560^{\circ} \mathrm{C}$, so the fuel thermal expansion is significant. (The calculated pellet centerline temperature is $749^{\circ} \mathrm{C}$.) Nevertheless, with pellet densifications of 2.0 percent, pellet-clad contact is not predicted to occur. As indicated in Table 2.1, the pellet-to-clad diametral gap just prior to reactor shutdown from Cycle $122 \mathrm{C}$ is calculated to be 1.00 mil.

For the pellets with maximum initial gaps, Table 2.1 indicates the expected larger (1.30 mil) calculated pellet-to-clad gap at the end of the irradiation. Also, since larger gaps imply smaller effective gap thermal conductances, the predicted temperatures for these pellets are higher.

Clad mechanical strain is predicted to have remained zero throughout the irradiation in all cases. Thus, clad strain is limited to that caused by thermal expansion (about 0.1 percent) and irradiation-induced clad creep (about 0.3 percent). Table 2.1 indicates calculated clad-to-capsule diametral gaps of between 1.12 and 2.06 mils at the end of the irradiation.

\subsection{Predicted Conditions for the Capsules in the Hot Cell}

The final burnup advancement steps in each CARTS calculation represent conditions from the time that the capsules arrive at ORNL (September 2000) through the time (January 2001) that the fuel pins are first opened for pellet inspection. For these three final calculation steps, the fuel pellets are heated internally by decay power, while heat transfer from the outer capsule surface is by convection to the hot cell atmosphere. 
Capsules 3 and 10 were introduced into the ORNL hot cell on September 19, 2000, about eight weeks after completion of irradiation and their removal from the ATR. The MOCUP protocol (coordinating calculations by MCNP and ORIGEN) was applied at INEEL to predict isotopic inventories and decay powers as documented in "As-Run Radiological Characterization of MOX Fuel Capsules Removed From The ATR After Cycle 122C - WKT-02-00," dated August 15, 2000. During the period from mid-September to mid-January, these results show that the pellet stack decay power falls from 2.7 to 1.5 watts $(0.0054$ to $0.0030 \mathrm{~kW} / \mathrm{ft})$.

The CARTS predictions for the capsule conditions at the expected time of opening are based on a decay power of 1.50 watts $(0.0030 \mathrm{~kW} / \mathrm{ft})$, which corresponds to mid-January 2001 . Heat transfer from the outer capsule surface is by free convection to the hot cell atmosphere. The natural convection heat transfer coefficient based on the capsule surface area directly over the pellet stack has been established as $27.5 \mathrm{~W} / \mathrm{m}^{2}-{ }^{\circ} \mathrm{C}\left(4.77 \mathrm{Btu} / \mathrm{hr}-\mathrm{ft}^{2}-{ }^{\circ} \mathrm{F}\right)$, based upon temperature measurements for the early- and intermediate-withdrawal capsules.

Table 2.2 presents the results of the CARTS calculations for conditions in the hot cell with decay heats corresponding to mid-January 2001. The final column of Table 2.2 indicates the predicted internal pressure within the fuel pins.

Table 2.2. CARTS predictions for Capsules 3 and 10 under hot cell conditions (mid-January 2001)

\begin{tabular}{|l|l|l|l|l|l|l|l|}
\hline \multirow{2}{*}{$\begin{array}{l}\text { Initial } \\
\text { pellet- } \\
\text { clad gap }\end{array}$} & \begin{tabular}{l} 
Temperatures ${ }^{\circ} \mathrm{C}$ \\
\cline { 2 - 8 } \\
centerline
\end{tabular} & Pellet mean & Clad wall & Capsule wall & $\begin{array}{l}\text { Pellet-to- } \\
\text { clad }\end{array}$ & $\begin{array}{l}\text { Clad-to- } \\
\text { capsule }\end{array}$ & $\begin{array}{l}\text { Fuel pinternal } \\
\text { pressure } \\
\text { psia }\end{array}$ \\
\hline Minimum & 40.6 & 40.5 & 40.1 & 40.0 & 2.24 & 0.98 & 33.4 \\
\hline Maximum & 40.7 & 40.6 & 40.1 & 40.0 & 2.72 & 1.98 & 33.4 \\
\hline
\end{tabular}

For the time of capsule opening, the pellet-to-clad diametral gaps within the fuel pins are predicted to lie between 2.24 and 2.72 mils, a range of 0.48 mil. Within this calculated range, the individual gap widths associated with the 15 different pellets are determined by the relative width of each pellet's initial cold diametral gap, which the design tolerances allow to lie between 2.0 and 3.5 mils.

The pressure within the fuel pins (based on the pellet-clad annular gap volume plus the gas plenum volume associated with the actual pellet stack length for these capsules) is predicted to be about 33.4 psia (18.7 psig). This result is obtained by use of an assumed fission gas (krypton and xenon) release from the fuel matrix in accordance with the best estimate $(4.5 \%$ at $50 \mathrm{GWd} / \mathrm{MT}$ ) as reported in Reference 7 . The fuel pin pressure measured for the intermediatewithdrawal $(21 \mathrm{GWd} / \mathrm{MT})$ capsules was in close agreement with the ESCORE-predicted pressure.

The diametral gap between the outer surface of the Zircaloy clad and the inner surface of the stainless steel capsule is calculated with the ESCORE fuel performance models (with representation of outward clad creep) to lie in the range between 0.98 and 1.98 mils. This onemil range strictly follows from the design tolerances, which permit the cold clad-to-capsule 
initial diametral gap to vary between 2.0 and 3.0 mils.

\subsection{Summary and Conclusions From the CARTS Predictions}

For Capsules 3 and 10, with burnups of $29.6 \mathrm{GWd} / \mathrm{MT}$, the CARTS code predicts that the 15 pellets within each fuel pin will exhibit, under hot-cell conditions, individual pellet-to-clad diametral gaps ranging from 2.24 to 2.72 mils. (Where internal cracks are present, the diametral gap is defined to include the width of these open cracks.)

Pellet-to-clad contact is not predicted to have occurred at any time during the irradiation. Thus, there was no clad mechanical strain or yielding of the clad Zircaloy. There was, however, evidence of irradiation-induced clad creep in the intermediate-withdrawal PIE. This creep, which introduces a permanent clad deformation, has been represented in the current calculations. The predicted change in fuel pin outer diameter is $1.10 \mathrm{mil}$, a $0.3 \%$ increase.

The diametral gap between the fuel pin and the capsule is predicted to lie between 0.98 and 1.98 mils, which may be compared to the range of 2.0-3.0 mils for the initial cold capsule assemblies. Here the separation between clad and capsule is reduced because of the outward clad creep.

These results suggest that fuel pin removal from the capsule and the subsequent fuel pin disassembly should be straightforward, without significant interference from either pin-tocapsule or pellet-to-clad binding.

Based on the best estimate for gas release from the fuel matrix, the gas pressure within the fuel pins under hot cell conditions is predicted to be about $33.4 \mathrm{psia}$ (18.7 psig). There are two factors, however, that might serve to increase the gas release. First, the LHGRs experienced during this test irradiation are somewhat higher than those normally encountered in the literature, and the higher fuel temperatures tend to increase the extent of fission gas release from the fuel matrix. Second, these fuel pellets have experienced 30 thermal cycles, about half again as many as would be expected for normal reactor operation at this burnup. Thus, the gas release may have been increased by a greater-than-normal extent of pellet thermal cracking. 


\section{3. “QUICK LOOK” PRELIMINARY PIE}

Table 3.1 details the items that have been selected for Step I of the PIE effort. Note that these items form a subset of the total PIE. The capsules made available for the $30 \mathrm{GWd} / \mathrm{MT}$ PIE effort are Capsule 3 (fuel prepared without gallium removal) and Capsule 10 (fuel prepared with gallium removal).

Table 3.1. Quick Look Metrology

\begin{tabular}{|r|l|l|}
\hline \hline \multicolumn{1}{|c|}{ No. } & \multicolumn{1}{|c|}{ Examination } & \multicolumn{1}{c|}{ Comments } \\
\hline \hline 1 & Capsule photo visual & Containment integrity is major interest. \\
\hline 2 & Capsule temperature measurement & $\begin{array}{l}\text { Compare measured temperatures with } \\
\text { predictions. }\end{array}$ \\
\hline 4 & Capsule dimensional inspection & Containment integrity is major interest \\
\hline 5 & Fission gas sampling & $\begin{array}{l}\text { Determine gross internal state of capsule } \\
\text { and fuel pin. }\end{array}$ \\
\hline \hline 6 & Fuel pin photo & $\begin{array}{l}\text { The fission gas pressure and }{ }^{85} \text { Kr content of } \\
\text { both the containment and the fuel pin will } \\
\text { be analyzed. }\end{array}$ \\
\hline \hline & Fuemove fuel pin from capsule \\
\hline \multicolumn{2}{|c|}{ from dimensional inspection } & $\begin{array}{l}\text { First assessment of clad integrity. (An } \\
\text { additional gamma scan may be performed if } \\
\text { the situation warrants.) }\end{array}$ \\
\hline
\end{tabular}

Note that the capsule and fuel pin numbering are not the same; Table 3.2 details the relationship between the two and identifies the status with respect to gallium removal treatment.

\subsection{Capsule Photo Visual Inspection}

The first portion of the PIE effort was to visually examine the capsule surfaces at low magnification. Both capsules appeared to be clean and bright with no sign of corrosion or damage. The black lines near the welding border are the heat-affected zone and are unrelated to the irradiation. In general, the stainless steel containment survived the irradiation as expected and these capsules appear no differently than the capsules previously removed at 8 and 21 GWd/MT. Photographs of these capsules are shown in Figures 3.1 through 3.6 for a variety of views. The two appear identical except for the identification marks. 
Table 3.2. Capsule and Fuel Pin Numbers

\begin{tabular}{|c|c|c|c|c|c|}
\hline $\begin{array}{l}\text { Capsule } \\
\text { Number } \\
\end{array}$ & $\begin{array}{l}\text { Fuel Pin } \\
\text { Number } \\
\end{array}$ & $\begin{array}{c}\text { Fuel } \\
\text { Batch } \\
\end{array}$ & $\begin{array}{c}\text { Gallium } \\
\text { Treatment } \\
\end{array}$ & $\begin{array}{c}\text { Exposure } \\
(\text { GWd/MT) } \\
\end{array}$ & PIE Status \\
\hline 1 & 2 & A & None & 8 & Complete -Pending clad ductility testing \\
\hline 2 & 5 & A & None & 21 & Complete-Pending clad ductility testing \\
\hline 3 & 6 & $\mathrm{~A}$ & None & 30 & Subject of this Quick Look \\
\hline 4 & 7 & $\mathrm{~A}$ & None & & In Reactor \\
\hline 5 & 8 & A & None & & In Reactor \\
\hline 6 & 9 & A & None & & In Reactor \\
\hline 7 & 10 & A & None & & Archive \\
\hline 8 & 11 & B & $\begin{array}{l}\text { Thermal } \\
\text { (TIGR) }\end{array}$ & 8 & Complete-Pending clad ductility testing \\
\hline 9 & 12 & B & $\begin{array}{l}\text { Thermal } \\
\text { (TIGR) }\end{array}$ & 21 & Complete-Pending clad ductility testing \\
\hline 10 & 13 & B & $\begin{array}{l}\text { Thermal } \\
\text { (TIGR) }\end{array}$ & 30 & Subject of this Quick Look \\
\hline 11 & 14 & B & $\begin{array}{l}\text { Thermal } \\
\text { (TIGR) }\end{array}$ & & Archive \\
\hline 12 & 15 & B & $\begin{array}{l}\text { Thermal } \\
\text { (TIGR) }\end{array}$ & & In Reactor \\
\hline 13 & 16 & B & $\begin{array}{l}\text { Thermal } \\
\text { (TIGR) }\end{array}$ & & In Reactor \\
\hline
\end{tabular}




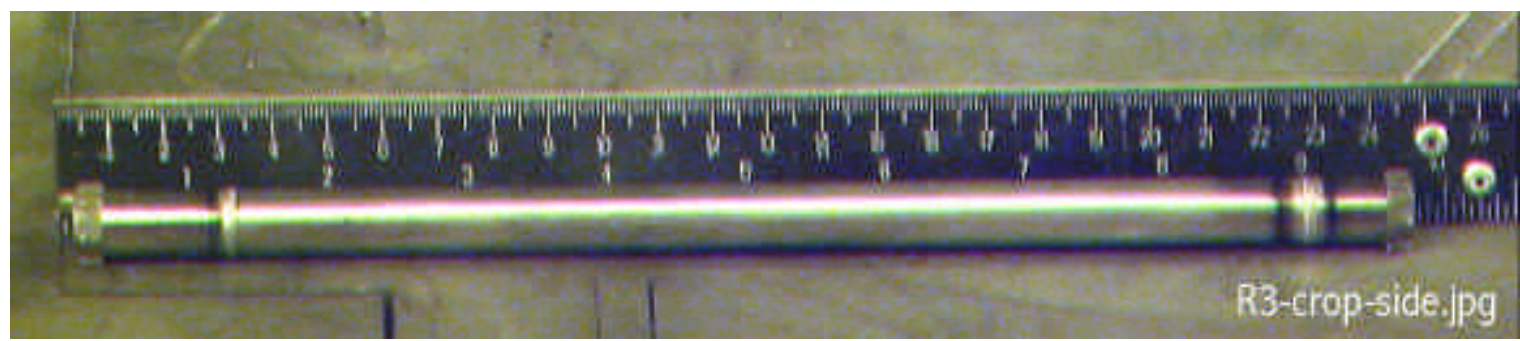

Figure 3.1. Side view of Capsule 3.

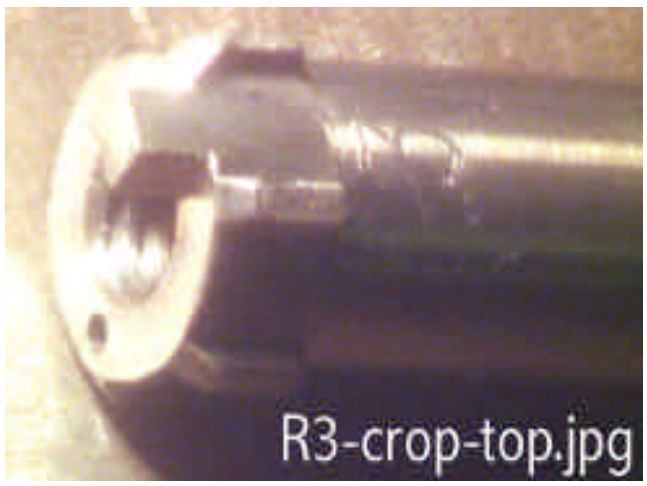

Figure 3.2. Top view of Capsule 3.

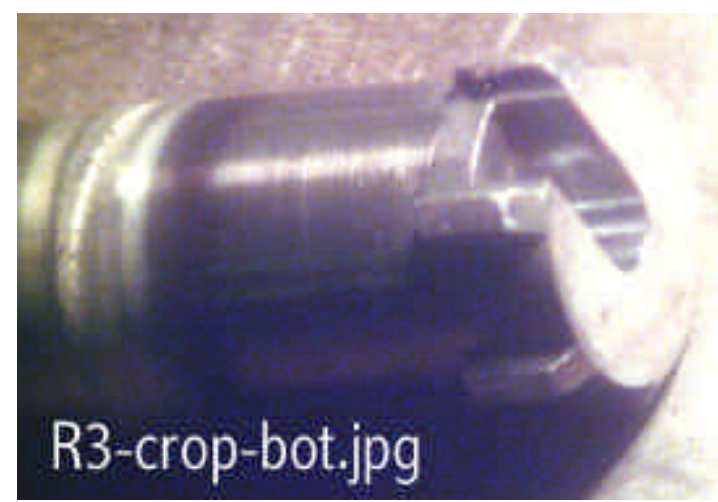

Figure 3.3. Bottom view of Capsule 3. 


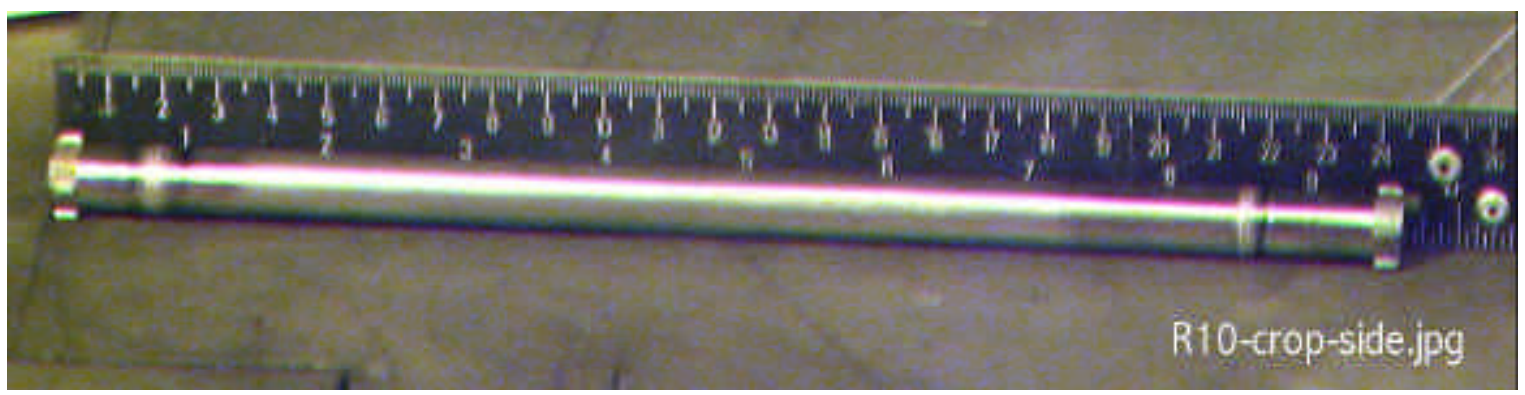

Figure 3.4. Side view of Capsule 10.

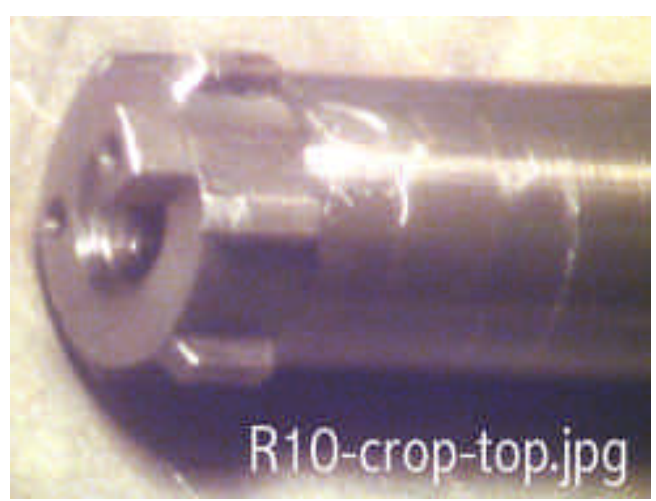

Figure 3.5. Top view of Capsule 10.

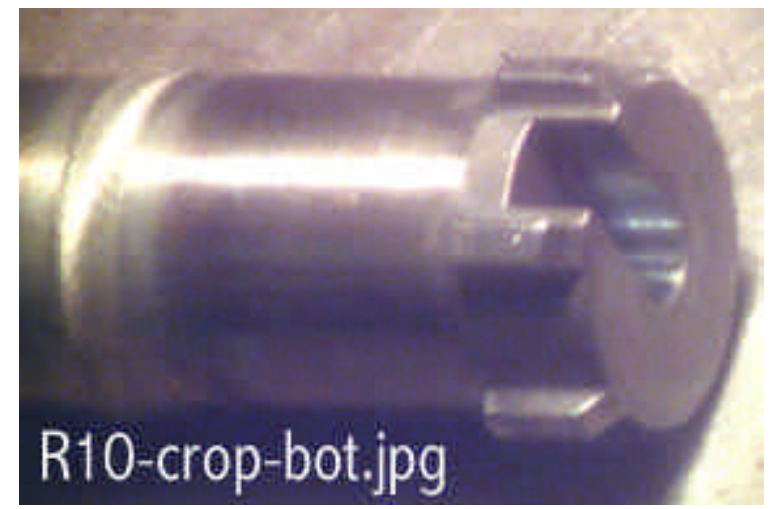

Figure 3.6. Bottom view of Capsule 10. 


\subsection{Capsule Temperature Measurements}

The temperature measurements and their locations as taken on Capsules 3 and 10 are shown in Table 3.3. A photo of a capsule undergoing a measurement is shown in Fig. 3.7. The apparatus consists of a Type $\mathrm{C}$ thermocouple held to the capsule by a modified hose clamp.

\section{Table 3.3. Capsule 3 and 10 Temperature Measurements}

\begin{tabular}{|l|l|}
\hline \hline \multicolumn{2}{|l|}{ MOX Capsule 3 } \\
\hline \hline Measurements taken on $09 / 27 / 2000$ from 0815 to 1050 \\
\hline Top Weld & $102.2^{\circ} \mathrm{F}\left(38.8^{\circ} \mathrm{C}\right)$ \\
\hline Mid Point & $117.8^{\circ} \mathrm{F}\left(47.5^{\circ} \mathrm{C}\right)$ \\
\hline Bottom Weld & $108.6^{\circ} \mathrm{F}\left(42.6^{\circ} \mathrm{C}\right)$ \\
\hline Average & $109.5^{\circ} \mathrm{F}\left(43.0^{\circ} \mathrm{C}\right)$ \\
\hline Cell Ambient & $80.4^{\circ} \mathrm{F}\left(26.8^{\circ} \mathrm{C}\right)$ \\
\hline \hline MOX Capsule $\mathbf{1 0}$ & \\
\hline \hline Measurements taken & on $09 / 27 / 2000$ from 1205 to 1450 \\
\hline Top Weld & $103.8^{\circ} \mathrm{F}\left(39.8^{\circ} \mathrm{C}\right)$ \\
\hline Mid Point & $118.2^{\circ} \mathrm{F}\left(47.8^{\circ} \mathrm{C}\right)$ \\
\hline Bottom Weld & $104.2^{\circ} \mathrm{F}\left(40.0^{\circ} \mathrm{C}\right)$ \\
\hline Average & $108.7^{\circ} \mathrm{F}\left(42.5^{\circ} \mathrm{C}\right)$ \\
\hline Cell Ambient & $86.2^{\circ} \mathrm{F}\left(30.0^{\circ} \mathrm{C}\right)$ \\
\hline
\end{tabular}

Notes:

Capsule temperature measurements were taken 10" from the hot cell tabletop and allowed to stabilize for 45 minutes. Fahrenheit and Centigrade values were determined by switching between instrument readouts, not mathematical conversion. These values are used to set the capsule surface heat transfer coefficient, as discussed in Section 2.6.

\subsection{Capsule Dimensional Inspection}

The results of the stainless steel capsule dimensional inspections are shown in Table 3.4. Within 0.001 inches, there were no indications of bowing or out of roundness. Measurements for bowing were carried out between the capsule welds. Only a slight difference between pre- and post-irradiation diametrical values was noted, less than 0.001 inches, which is due to the thermal expansion associated with the somewhat higher measurement temperatures in the hot cell. The lengths of the capsules were found to agree with the preirradiation values within 0.01 inches. Figure 3.8 details the measurement method for radial dimensions. 


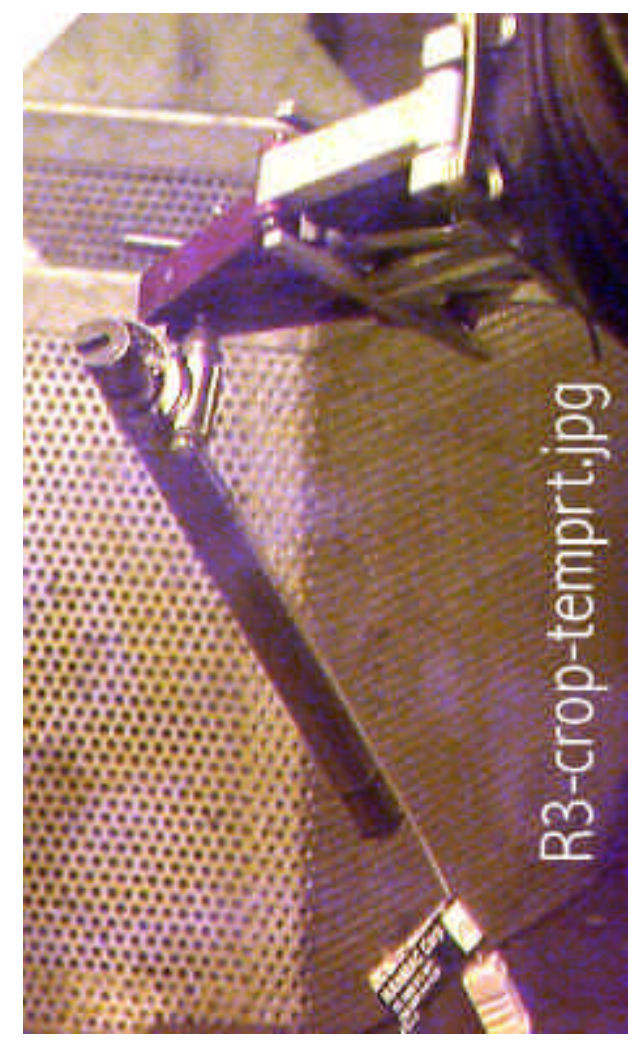

Figure 3.7. Free air temperature measurement on Capsule 3.

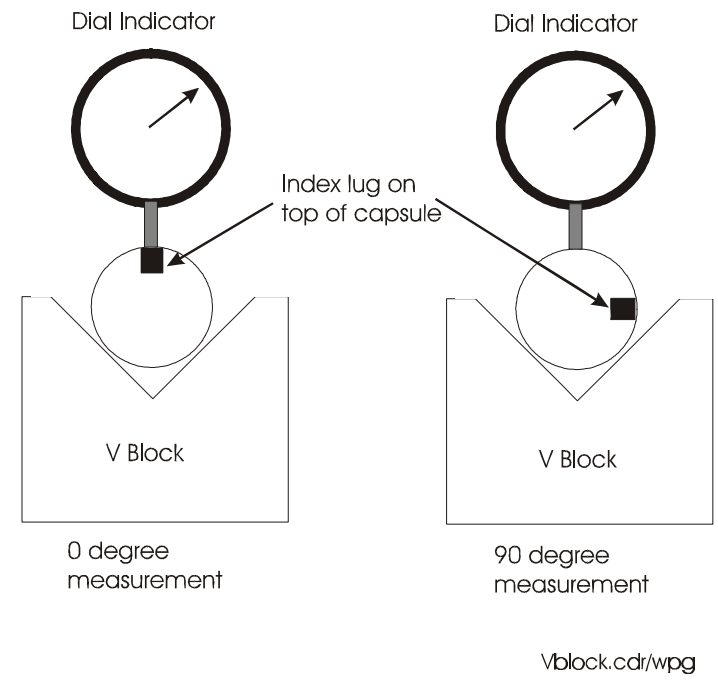

Figure 3.8. Schematic of diameter measurement. 
Table 3.4. Capsule Measurements

\begin{tabular}{|c|c|c|c|}
\hline \multirow[t]{2}{*}{ Axial Location } & \multicolumn{2}{|c|}{$\begin{array}{c}\text { Diameter Measurements (in) } \\
( \pm 0.0005 \text { in })\end{array}$} & \multirow{2}{*}{$\begin{array}{c}\text { Preirradiation Value } \\
\text { (Room Temperature) } \\
\text { (in) }\end{array}$} \\
\hline & $\mathbf{0}^{\circ}$ & $90^{\circ}$ & \\
\hline \multicolumn{4}{|l|}{ Capsule 3} \\
\hline 3.4" from capsule top & 0.4655 & 0.4655 & \multirow{3}{*}{0.4643 to 0.4649} \\
\hline Center of capsule & 0.4657 & 0.4656 & \\
\hline 5.8" from capsule top & 0.4657 & 0.4654 & \\
\hline \multicolumn{4}{|l|}{ Capsule 10} \\
\hline 3.8" from capsule top & 0.4651 & 0.4649 & \multirow{3}{*}{0.4643 to 0.4649} \\
\hline Center of capsule & 0.4649 & 0.4651 & \\
\hline 5.8" from capsule top & 0.4650 & 0.4649 & \\
\hline \multicolumn{4}{|c|}{$\begin{array}{l}\text { Length (in) } \\
( \pm 0.005 \text { in })\end{array}$} \\
\hline Capsule 3 & & 9.585 & $\begin{array}{r}9.575 \text { after welding } \\
\text { (9.59 before welding) }\end{array}$ \\
\hline Capsule 10 & & 9.581 & $\begin{array}{r}9.576 \text { after welding } \\
\text { (9.59 before welding) }\end{array}$ \\
\hline \multicolumn{4}{|c|}{$\begin{array}{l}\text { Mass }(g) \\
( \pm 0.1 \text { in }) \\
\end{array}$} \\
\hline Capsule 3 & & 191.1 & Not given \\
\hline Capsule 10 & & 192.9 & Not given \\
\hline
\end{tabular}

\subsection{Capsule Gamma Scans}

Both Capsules 3 and 10 were raster-scanned to obtain a two dimensional view of the capsule internal structure. These scans comprise 6000 points and were taken with a 1/16" diameter collimator in two energy ranges. The range 400 to $700 \mathrm{KeV}$ was employed to broadly cover the fission products while the range 800 to $1575 \mathrm{keV}$ was used to broadly cover the activation products. These two energy ranges were selected because they show the most details of interest for a general view.

In addition, both capsules underwent an axial line scan (400 points) along their length using the same collimator as was used in the two-dimensional scans. Results from these two energy ranges are presented in the following Sections. Overall, the capsules appeared to be intact with no unusual structure or abnormalities.

\subsubsection{Capsule 3 Gamma Scan}

Figure 3.9 shows the result of the 400 to $700 \mathrm{KeV}$ raster scan for Capsule 3. When compared to the schematic above, one can make out the stainless steel end caps, the fuel pin end caps, and very clearly, the fuel pellet stack. The pedestal at the base of the lower fuel pin end plug is vaguely outlined as well as is the capsule boundary (the capsule bottom is to the left, the top to the right). 
The Nominal Fuel Pin Schematic Has Been Shifted Within the

Capsule and the Fuel stack and Spring Scaled to Model the Scan

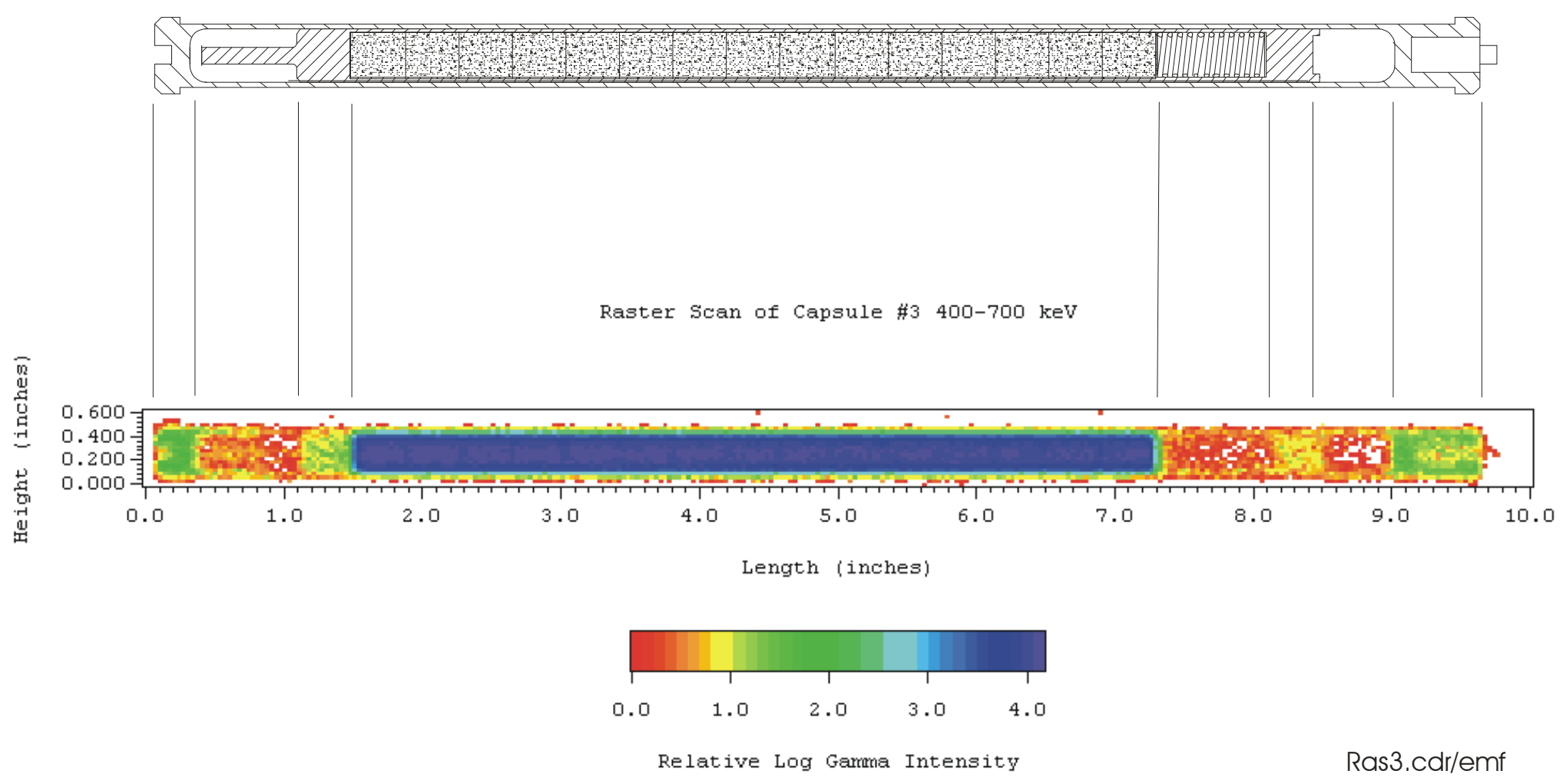

Figure 3.9. Capsule 3 mid energy gamma raster scan. 
Figure 3.10 shows the raster scan for Capsule 3 in the 800 to $1575 \mathrm{keV}$ energy range. This higher energy range outlines the stainless steel components to a greater degree.

Figure 3.11 shows an axial line scan along the capsule in the 400 to $700 \mathrm{keV}$ energy range. Again, the elements of the capsule are clearly indicated. The fuel pellet stack appears to be about 5.8 inches long, as expected. The pellet locations can be estimated by the signal dips caused by the pellet dishing in this scan. The general decrease in fission product activity along the pellet stack from bottom to top corresponds to the ATR flux shape at the position within the test assembly where this capsule was located during the irradiation.

Figure 3.12 shows an axial line scan in the energy range of $800-1575 \mathrm{KeV}$, which accents the stainless steel activation products. This figure shows the stainless steel capsule end caps and wall more clearly. The fuel can be seen because of the high energy fission product emitters such as ${ }^{140}$ La.

Overall, the capsule showed no structural problems. All components appeared to be in their proper locations and the fuel pellet stack does not appear to have swelled significantly. 
The Nominal Fuel Pin Schematic Has Been Shifted Within the

Capsule and the Fuel stack and Spring Scaled to Model the Scan

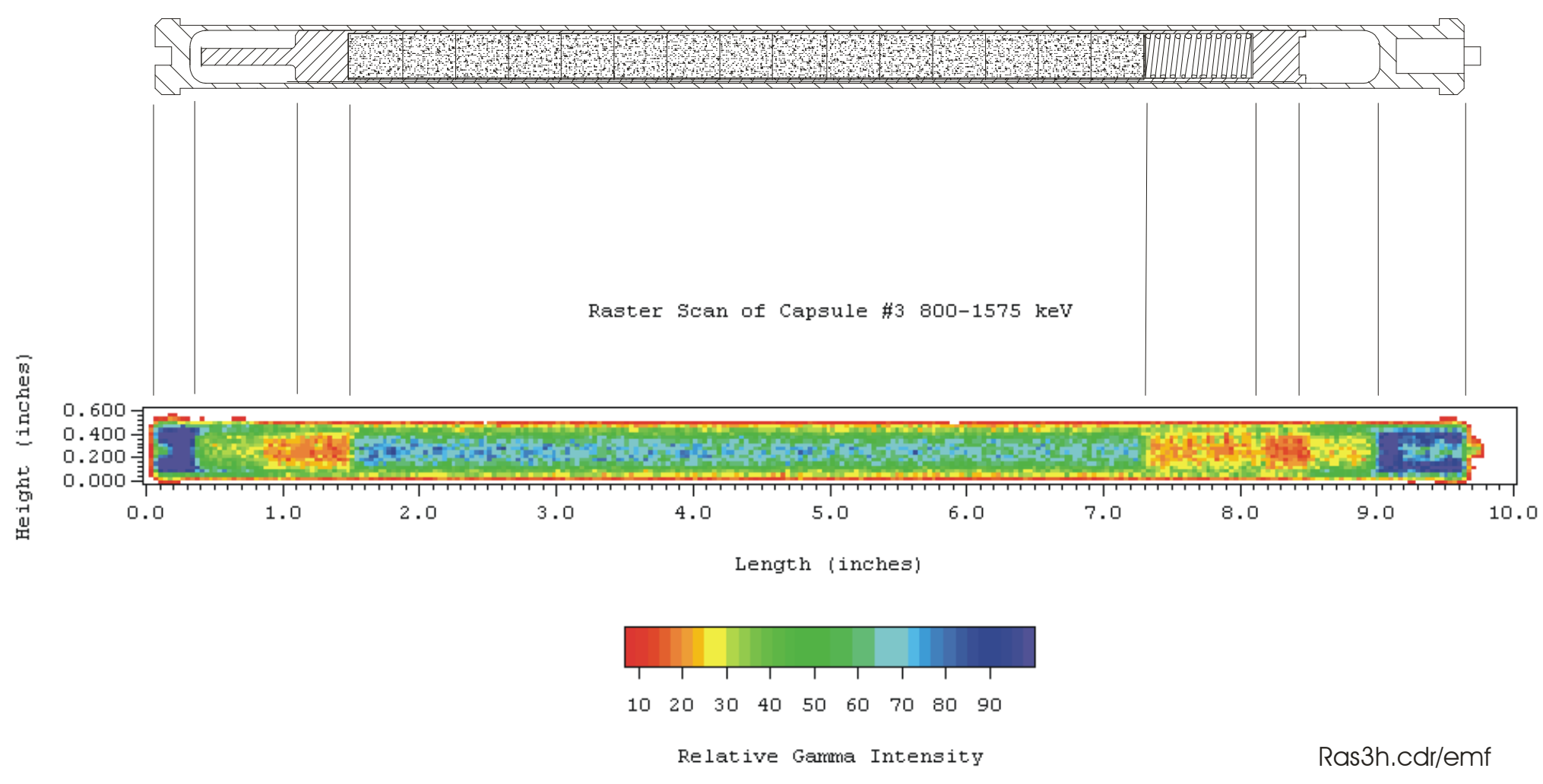

Figure 3.10. Capsule 3 high energy gamma raster scan. 
The Nominal Fuel Pin Schematic Has Been Shifted Within the

Capsule and the Fuel Stack and Spring Scaled to Model the Scan

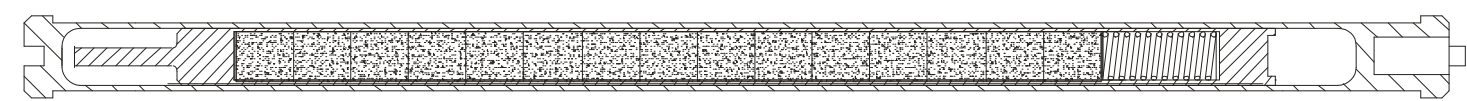

Capsule 3 Axial Garma Scan 400-700 keV

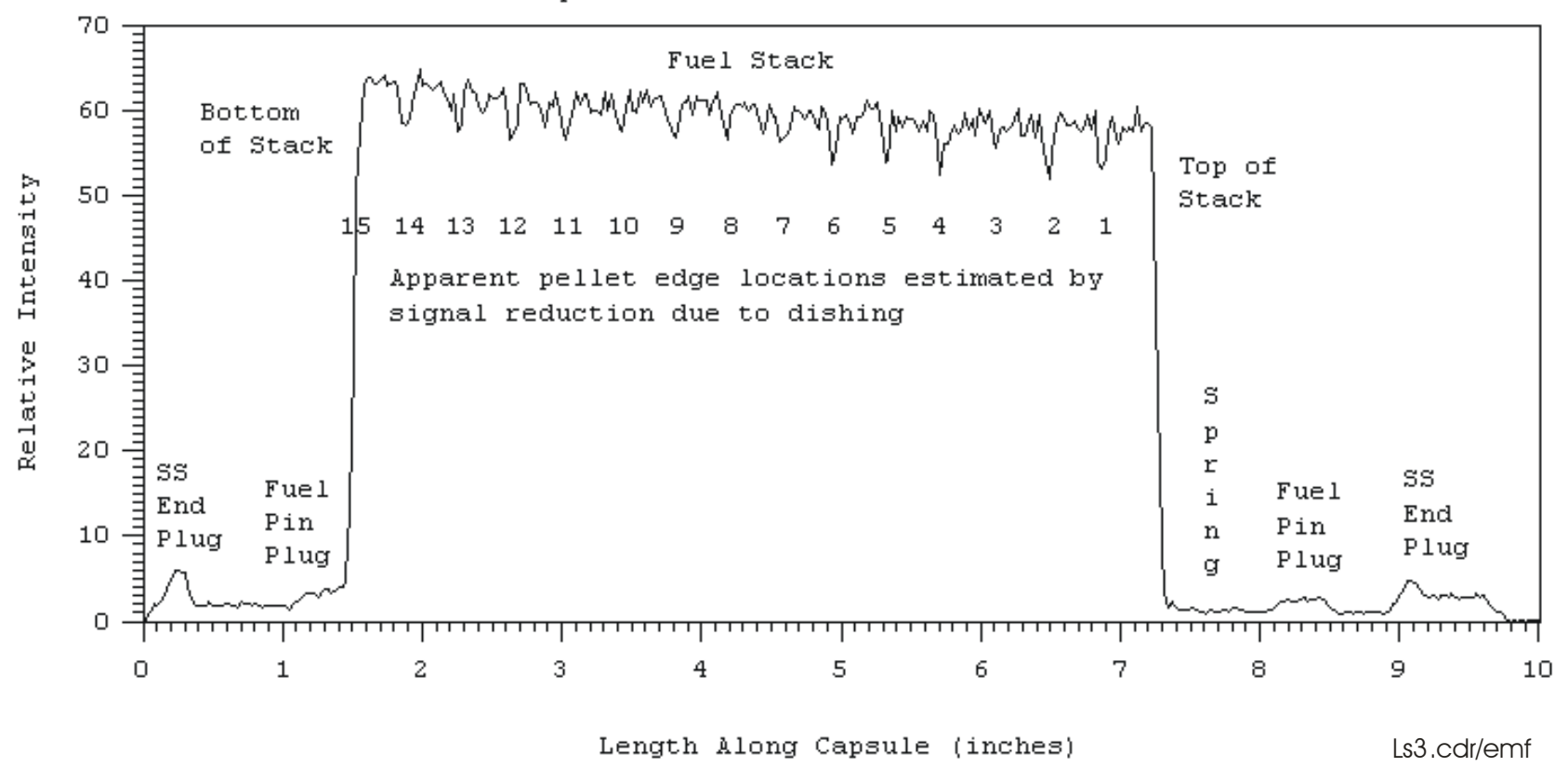

Figure 3.11. Capsule 3 mid energy gamma line scan. 
The Nominal Fuel Pin Schematic Has Been Shifted Within the

Capsule and the Fuel Stack and Spring Scaled to Model the Scan

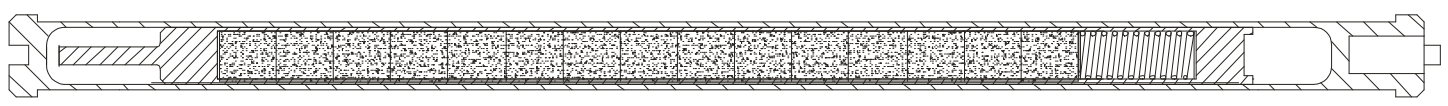

Capsule 3 Axial Garma Scan 800-1575 keV

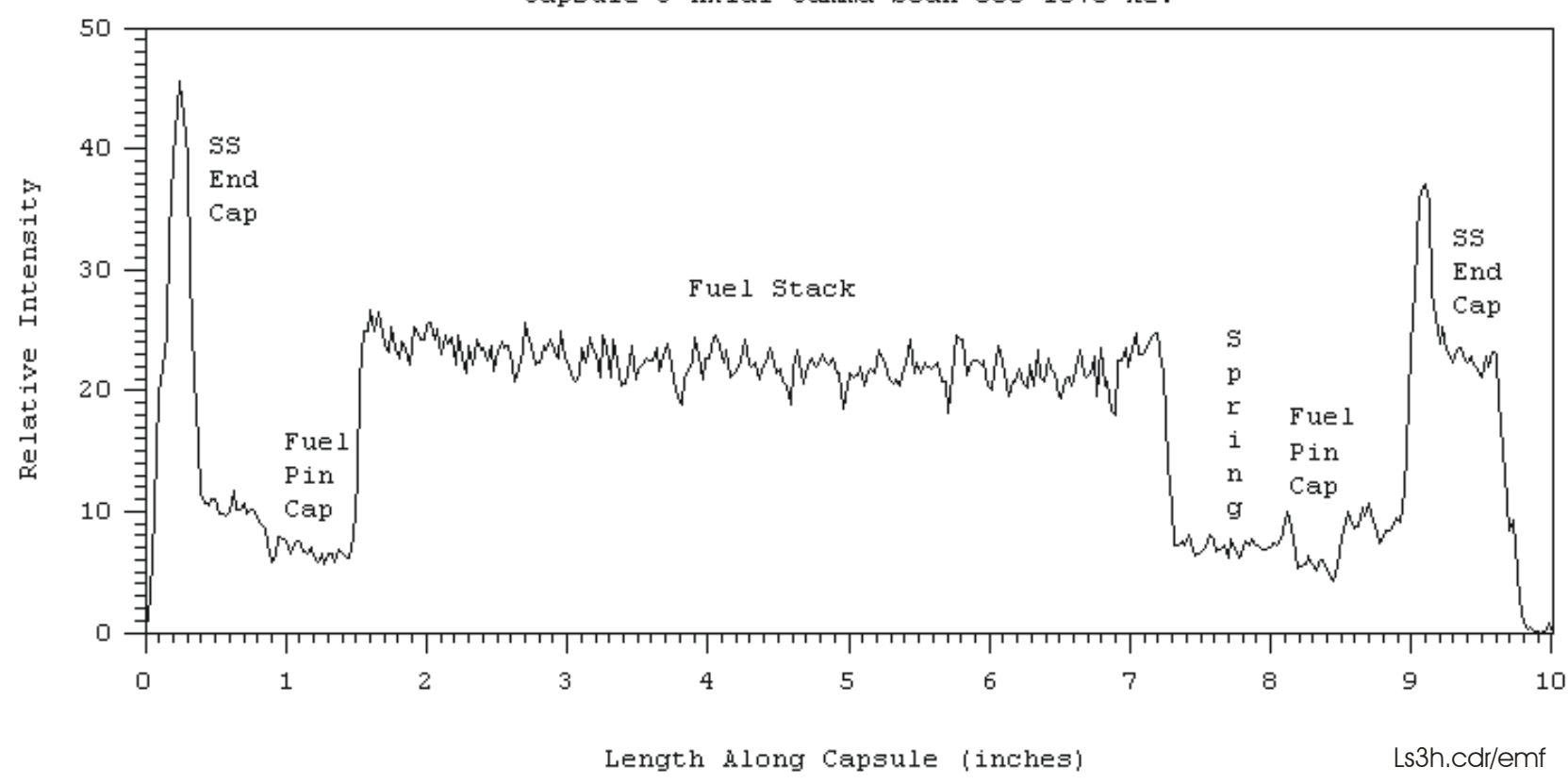

Figure 3.12. Capsule 3 high energy gamma line scan. 


\subsubsection{Capsule 10 Gamma Scan}

Figure 3.13 shows the results of the 400 to $700 \mathrm{keV}$ raster scan for Capsule 10. As before, one can make out the stainless steel end caps, the fuel pin end caps, and the fuel pellet stack. Figure 3.14 shows the same scan in the 800 to 1575 energy range. No inconsistencies or abnormalities in internal component locations were noted.

Figure 3.15 shows an axial line scan along Capsule 10 in the 400 to $700 \mathrm{keV}$ energy range. Again, the elements of the capsule are visible. The fuel stack appears to be approximately 5.8 inches long, but in this case the pellet dishing cannot be seen. Note the decrease in fission product activity along the pellet stack as was seen in Figure 3.11 for Capsule 3 .

Figure 3.16 shows an axial line scan in the energy range of $800-1575 \mathrm{KeV}$, which accents the stainless steel activation products.

Similar to Capsule 3, Capsule 10 appears to have no major structural problems and all components appear to be in their proper locations with no significant axial fuel swelling. 
The Nominal Fuel Pin Schematic Has Been Shifted Capsule and the Fuel Stack and Spring Scaled to Model
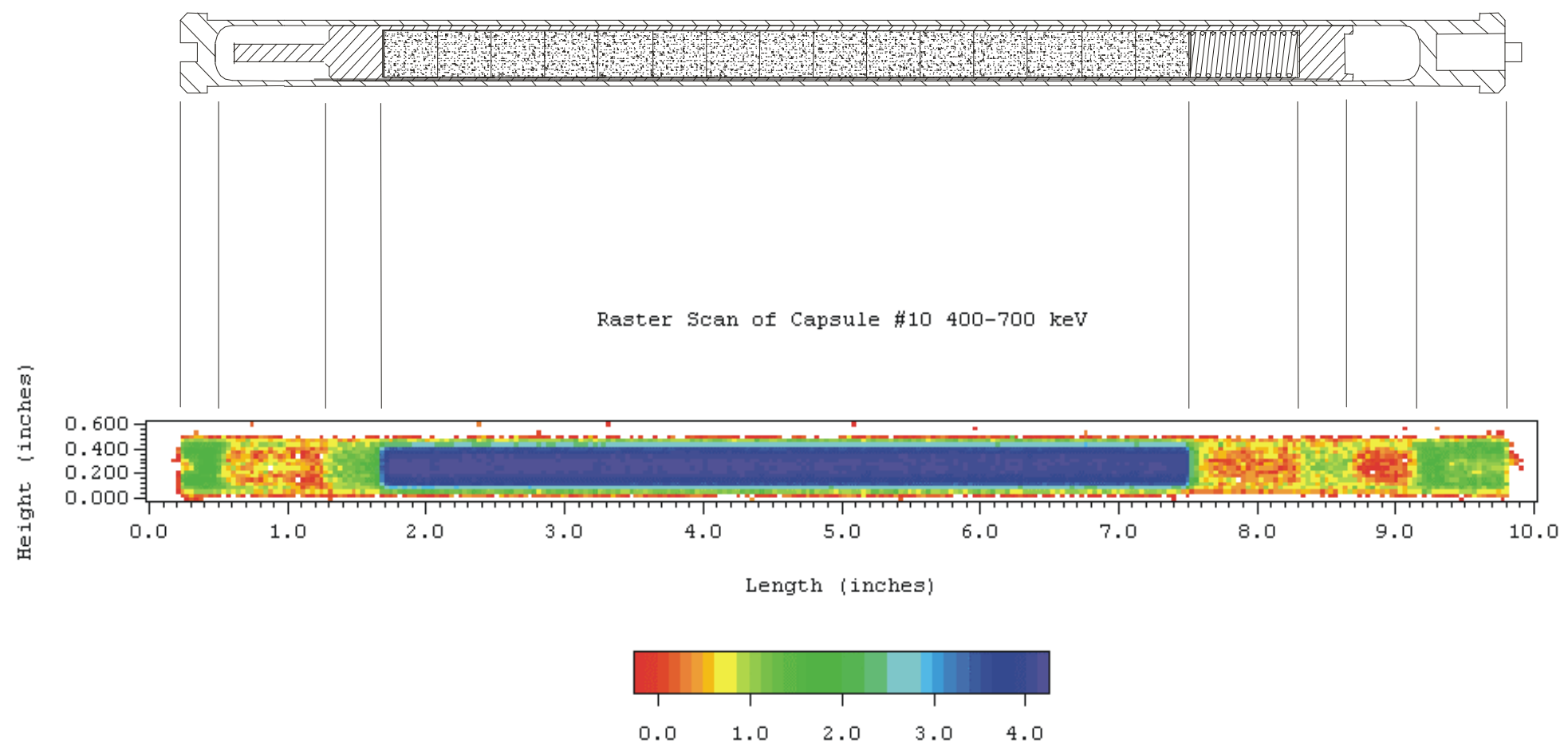

Relative Log Garma Intensity

Ras10.cdr/e

Figure 3.13. Capsule 10 mid energy gamma raster scan. 
The Nominal Fuel Pin Schematic Has Been Shifted Within the

Capsule and the Fuel Stack and Spring Scaled to Model the Scan

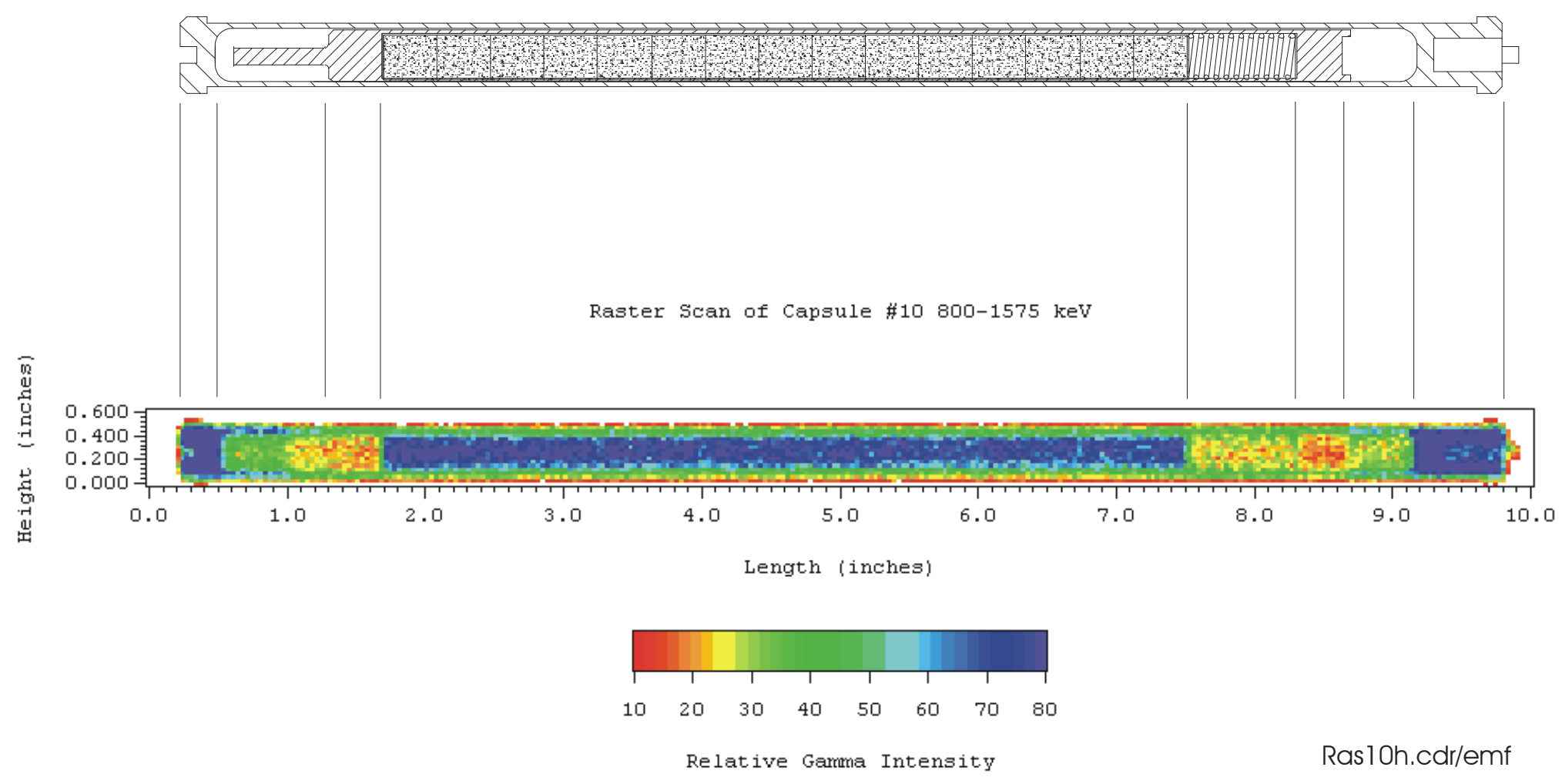

Figure 3.14. Capsule 10 high energy gamma raster scan. 
The Nominal Fuel Pin Schematic Has Been Shifted Within the Capsule and the Fuel Stack and Spring Scaled to Model the Scan

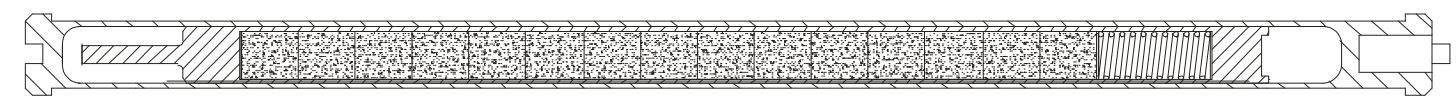

Capsule 10 Axial Gamma Scan $400-700 \mathrm{keV}$

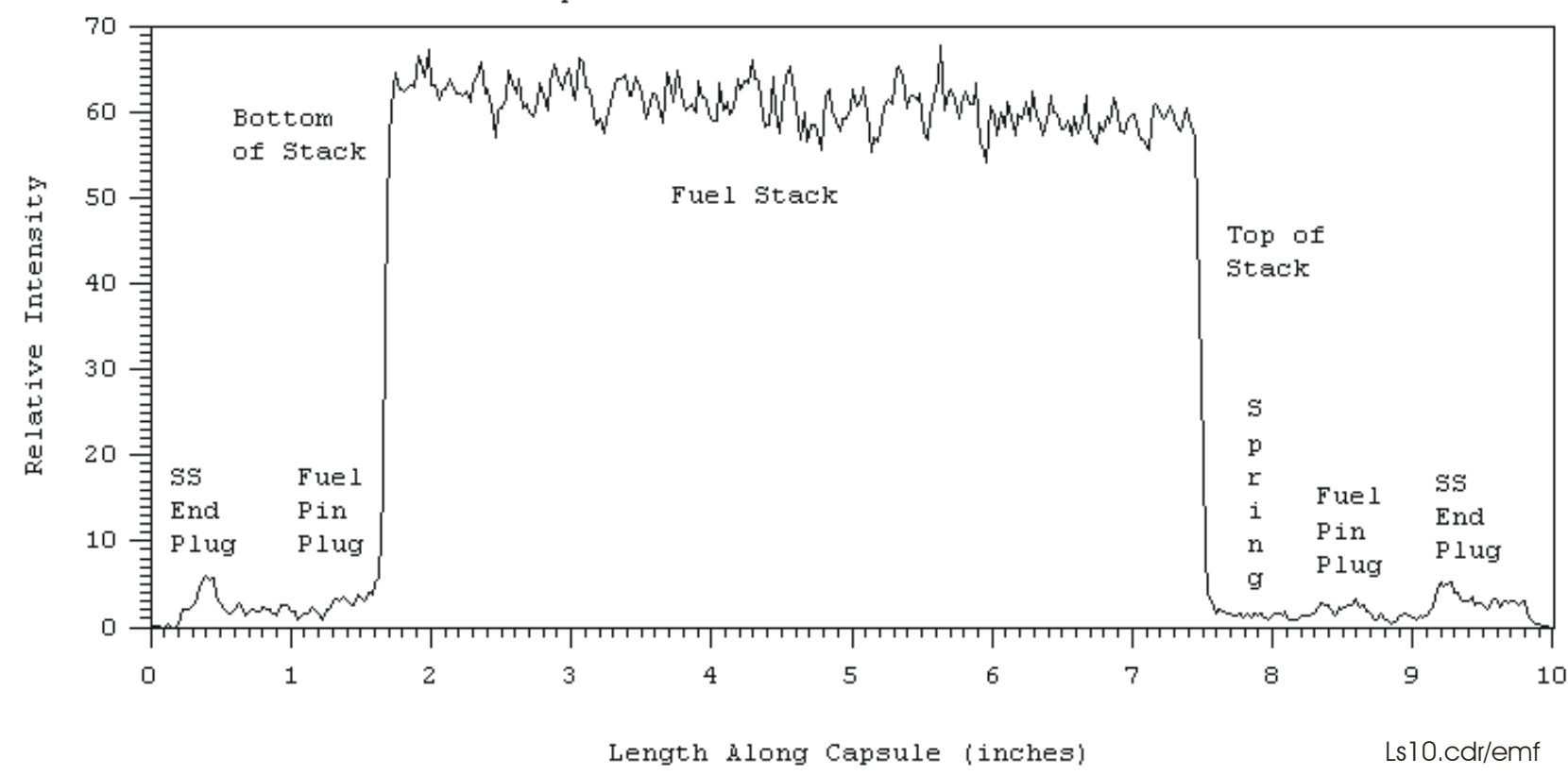

Figure 3.15. Capsule 10 mid energy gamma line scan. 
The Nominal Fuel Pin Schematic Has Been Shifted Within the Capsule and the Fuel Stack and Spring Scaled to Model the Scan
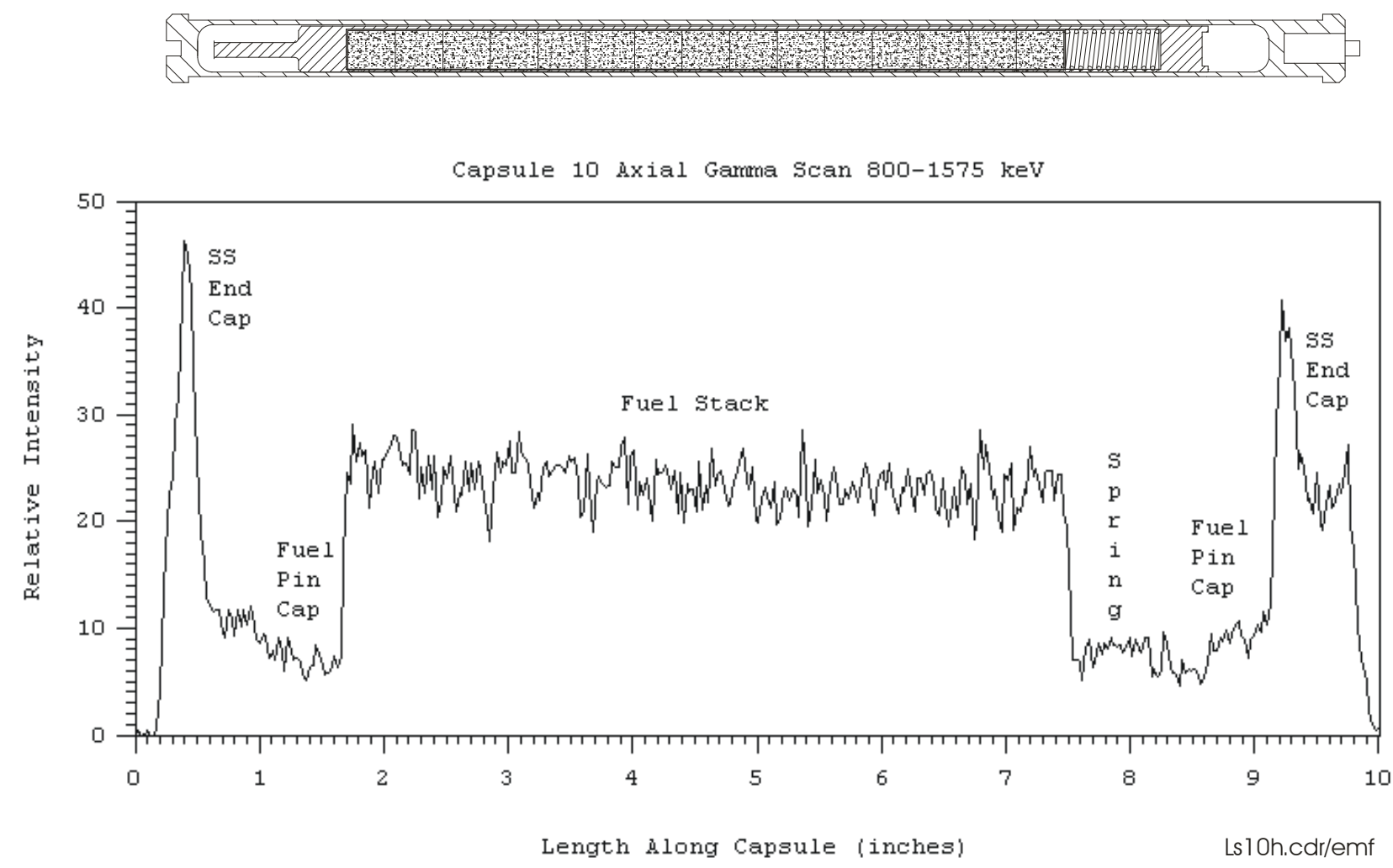

Figure 3.16. Capsule 10 high energy gamma line scan. 


\subsubsection{Gamma Scanner Data Collection Orientation}

The gamma intensity data was collected with the alignment lug of the capsule facing the gamma scanner detector as shown in Figure 3.17.

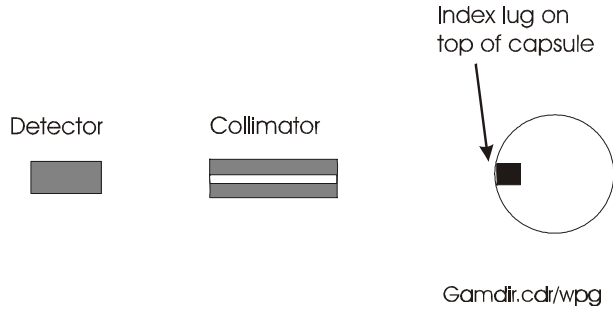

Figure 3.17 Orientation of the capsule and the gamma scanner collimator/detector.

\subsection{Fission Gas Measurements}

The fission gas pressure and ${ }^{85} \mathrm{Kr}$ content in both Capsules 3 and 10 and their associated fuel pins were measured by use of the MOX Fission Gas Pressure Measuring Apparatus. Details of this apparatus and its calibration are described in Ref. 8 and the first use of the device was in the PIE of the $21 \mathrm{GWd} / \mathrm{MT}$ capsules [Ref. 5]. Briefly, the apparatus functions by using a vacuum sealed drill-press like action to drill first through the trimmed off top of the MOX capsule and then, after sampling the gas in the capsule upper plenum region, to continue drilling into the contained fuel pin. The drilling stops as each barrier is penetrated to permit measurement of the gas pressure and sweeping of the released gases through a cold trap system to trap and determine the ${ }^{85} \mathrm{Kr}$ quantity. A diagram of the device is shown in Figure 3.18.

No anomalous fission gas release was observed in either capsule. The capsule pressures were subatmospheric, as expected since they were sealed at the elevation of INEEL, where the atmospheric pressure is about 12.5 psia. (The actual pressure in the capsule during welding could not be recorded.) The fuel pins were found to be sealed and the fission gas release was found to be in the range of 1.50 to $2.26 \%$ (based on ${ }^{85} \mathrm{Kr}$ ). No problems occurred with the apparatus. The details are summarized in Table 3.5. 


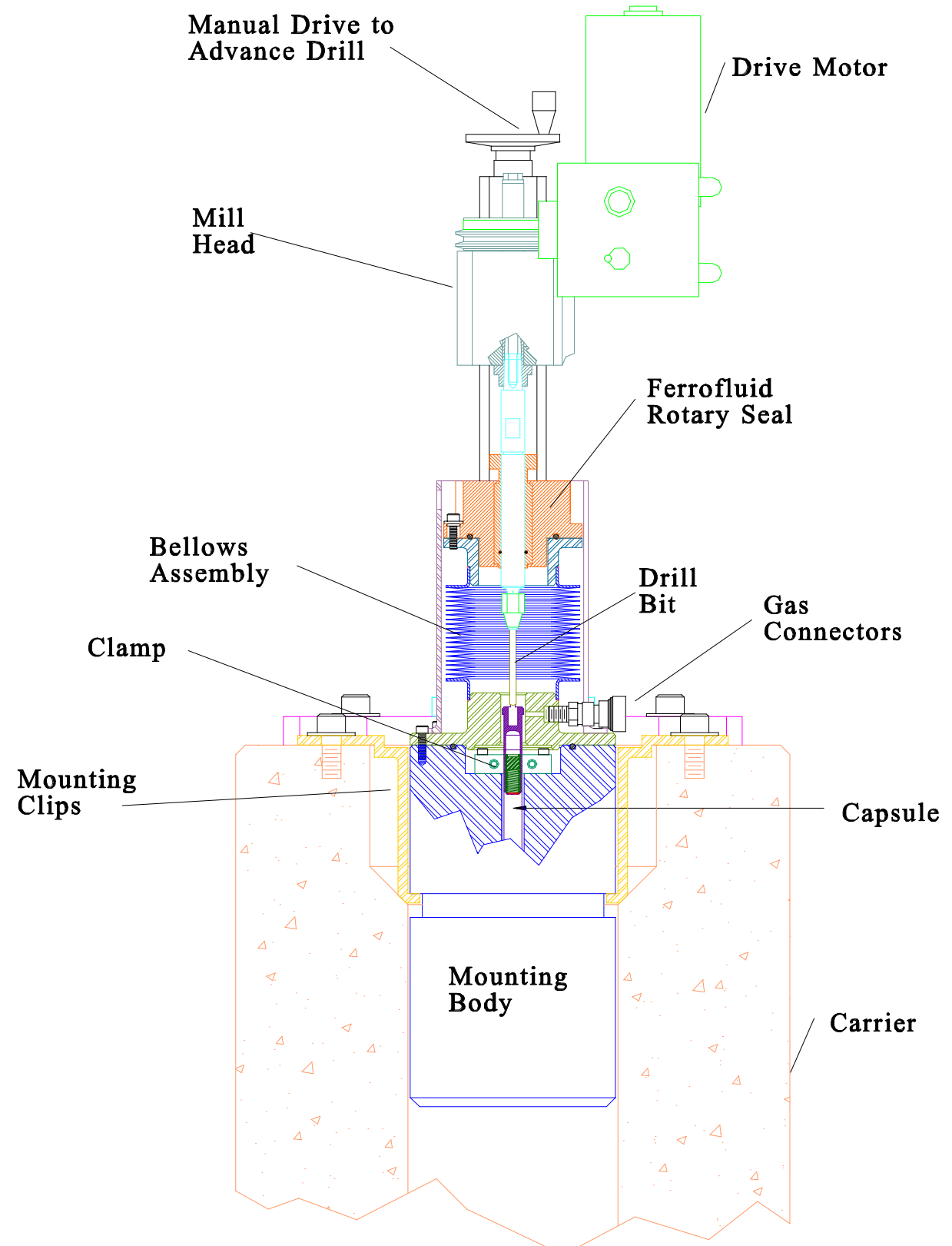

Figure 3.18. Cross sectional view of the Fission Gas Pressure Measuring Apparatus. [Drill Schematic 3.wpg] 
Table 3.5. Fission Gas Measurement

\begin{tabular}{|c|c|c|c|c|c|c|}
\hline Item & $\begin{array}{l}\text { Best Estimate } \\
\text { Free Volume } \\
\text { (cc) }\end{array}$ & $\begin{array}{c}\text { Measured } \\
\text { Pressure } \\
\text { (psia) }\end{array}$ & $\begin{array}{l}\text { Measured }{ }^{85} \mathrm{Kr} \\
\text { in Free Volume } \\
(\mathrm{mCi})\end{array}$ & $\begin{array}{c}\text { Best Estimate } \\
\text { for Total }{ }^{85} \mathrm{Kr} \\
\text { Inventory } \\
\text { (mCi) }\end{array}$ & $\begin{array}{l}\text { Model } \\
\text { Predicted } \\
\text { Pressure }^{3} \\
\quad \text { (psia) } \\
\end{array}$ & $\begin{array}{c}\text { Release } \\
\text { Fraction Based } \\
\text { on }{ }^{85} \mathrm{Kr} \\
\text { Measurement }\end{array}$ \\
\hline Capsule 3 & 2.397 & 10.4 & 0.00 & 0 & N/A & N/A \\
\hline Fuel Pin 6 & 1.239 & 28.5 & 6.18 & 413 & 33.4 & 0.0150 \\
\hline Capsule 10 & 2.397 & 10.2 & 0.00 & 0 & N/A & N/A \\
\hline Fuel Pin 13 & 1.302 & 35.1 & 9.26 & 410 & 33.4 & 0.0226 \\
\hline
\end{tabular}

${ }^{1}$ Based on actual dimensional measurements and code predicted fuel swelling

${ }^{2}$ Based on ORIGEN calculations (Ref. 9) for the time of drilling

${ }^{3}$ Based on CARTS calculations with an estimated release fraction corresponding to $4.5 \%$ at $50 \mathrm{GWd} / \mathrm{MT}$ and nominal fuel pellet stack length dimensions (Chapter 2)

Ambient temperature of $23^{\circ} \mathrm{C}$

Measured values are approximately $\pm 8 \%$ for pressure and $\pm 6 \%$ for ${ }^{85} \mathrm{Kr}$ 


\subsection{Fuel Pin Photo Visual Inspections}

Fuel Pin 6 was removed from Capsule 3 by cutting off the bottom of the capsule just above the weld. This operation also removed about two thirds of the pedestal at the base of the fuel pin. After deburring the capsule body, the fuel pin was removed by grasping and pulling on the stub of the bottom pedestal. The pin slid out with some minor difficulty. After removal, the pin was photographed and measured. The exterior of Fuel Pin 6 was found to be in excellent condition.

No attempt was made to maintain the angular orientation of the fuel pin relative to the capsule index lug because the fuel pin is not locked within the capsule during irradiation. Photographs of the fuel pin are shown in Figures 3.19 through 3.21.

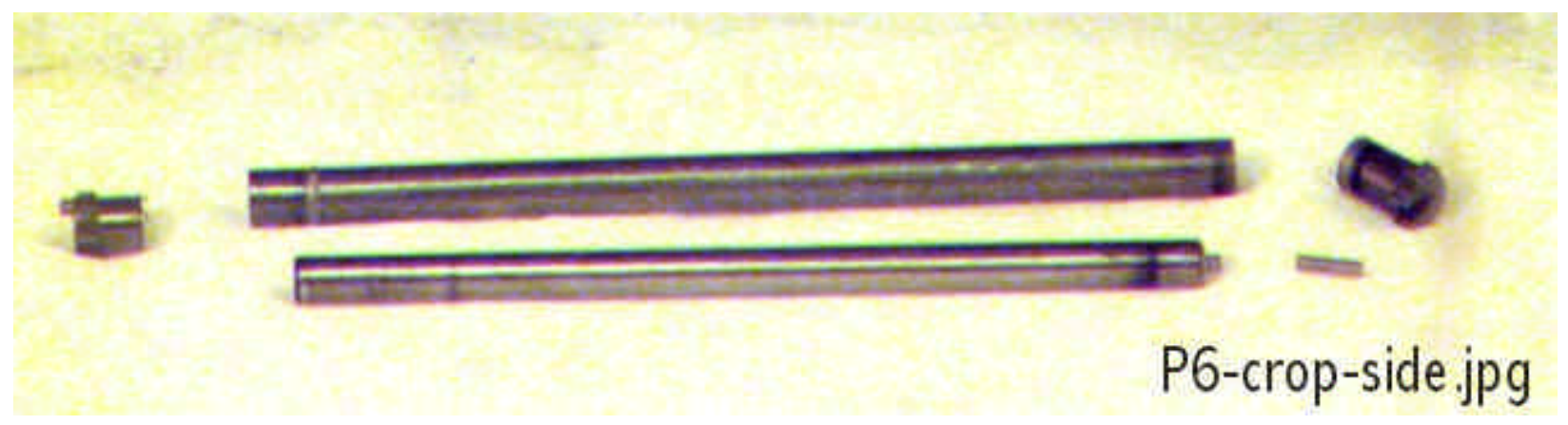

Figure 3.19. Side view of Fuel Pin 6 (foreground). Shown in the background are the components of the capsule and the cut off portion of the fuel pin pedestal. The black rings near the ends are due to welding.

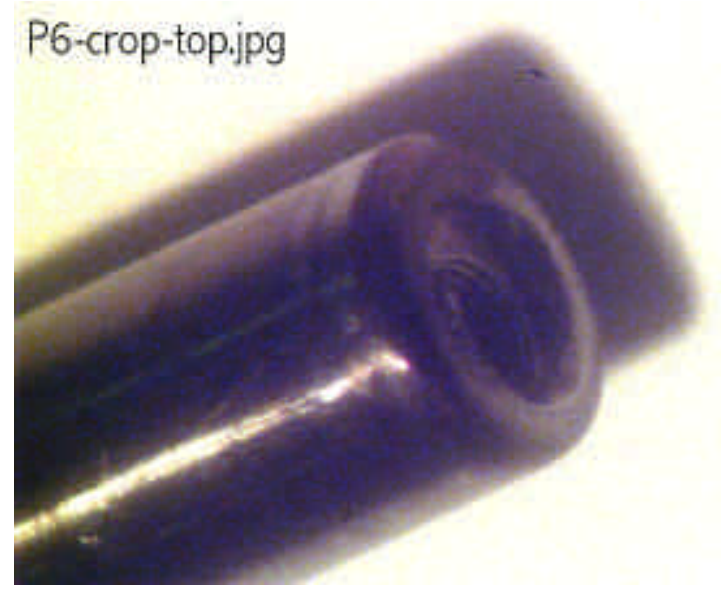

Figure 3.20. Top view of Fuel Pin 6. The lighting partially obscures the puncture hole. 


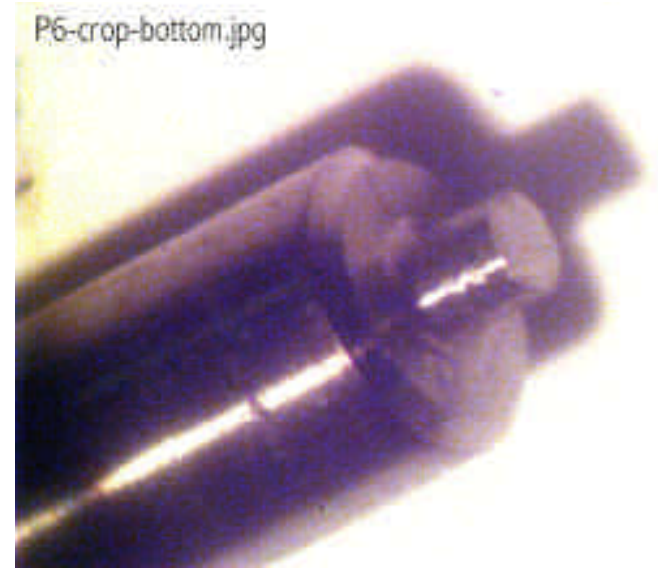

Figure 3.21. Bottom view of Fuel Pin 6.

Fuel pin 13 was removed from Capsule 10 in the same manner that Fuel Pin 6 was removed from Capsule 3. The exterior of Fuel Pin 13 was also found to be in excellent condition. Photographs of Fuel Pin 13 are shown in Figs. 3.22 through 3.24.

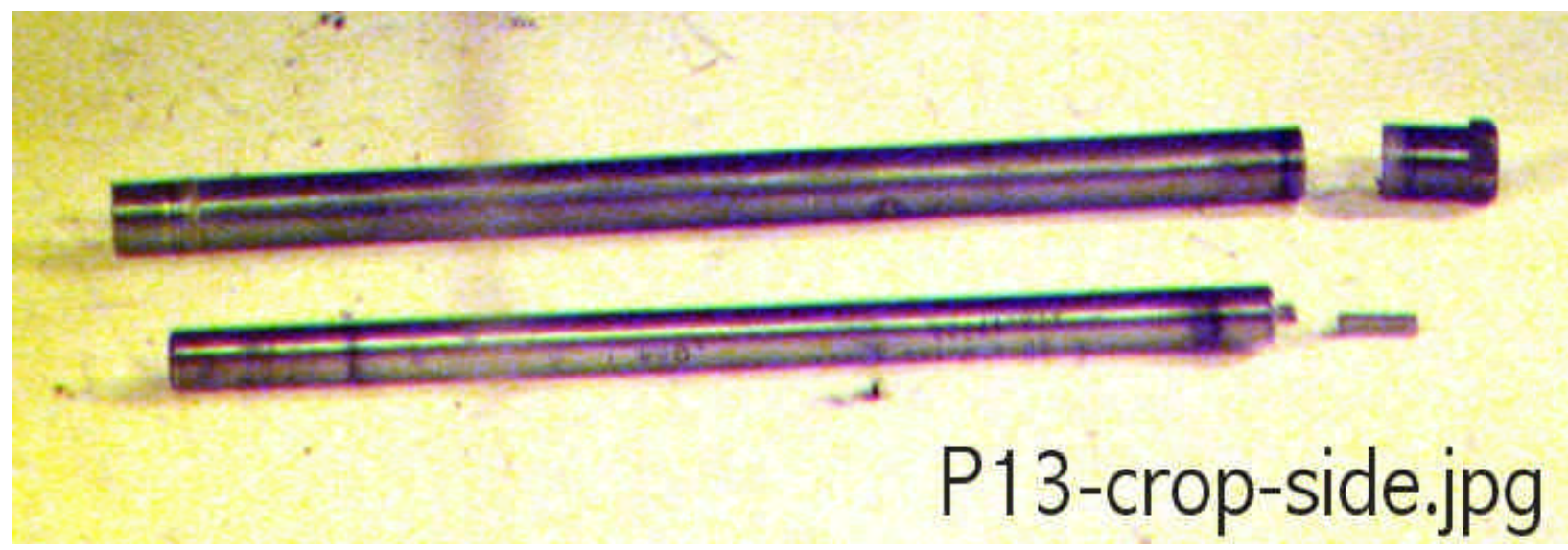

Figure 3.22. Side view of Fuel Pin 13 (foreground). Shown in the background are the components of the capsule and the cut off portion of the fuel pin pedestal. The black rings near the ends are due to welding and the marks on the side of the pin are tubing lot information. 


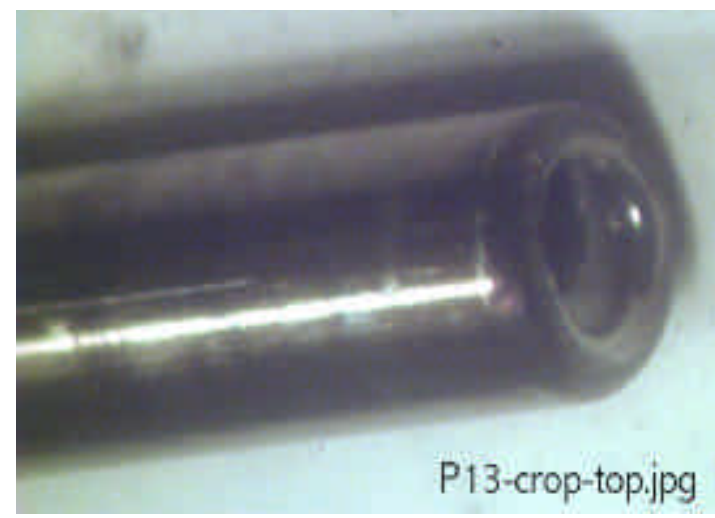

Figure 3.23. Top view of Fuel Pin 13. The lighting partially obscures the puncture hole.

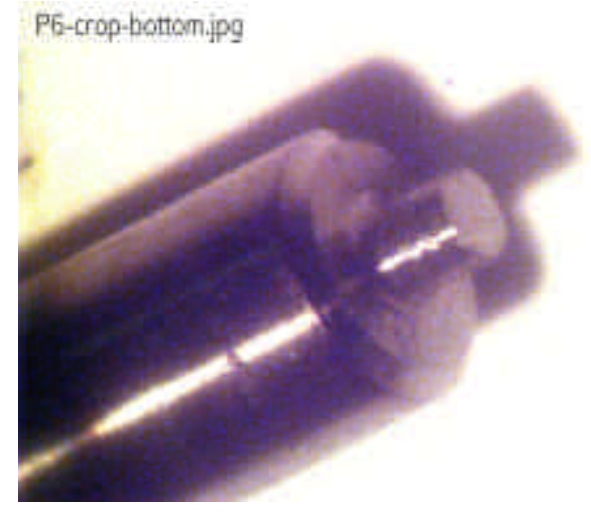

Figure 3.24. Bottom view of Fuel Pin 13.

\subsection{Fuel Pin Dimensional Inspections}

Because of the desire to examine the fuel pin clad for indications of pellet contact or creep, a somewhat more complex measuring device was used for this Quick Look than has been used in previous MOX ATR PIEs. The basis of operation is still a V block and dial indicator, but the diametrical accuracy is better ( \pm 0.0001 inches), this device is more convenient to use, and the axial position at which measurements are taken is more clearly resolved. A photo of the device in the hot cell is shown in Figure 3.25 and a schematic of the metric references is detailed in Figure 3.26.

The fuel pin is measured at four angles relative to an arbitrary zero. The four diameter measurements are noted for indications of out-of-roundness and then averaged to form one value for the pin diameter at each axial position. Measurements were taken at quarter-inch intervals 
over the region of the fuel pin containing the fuel stack.

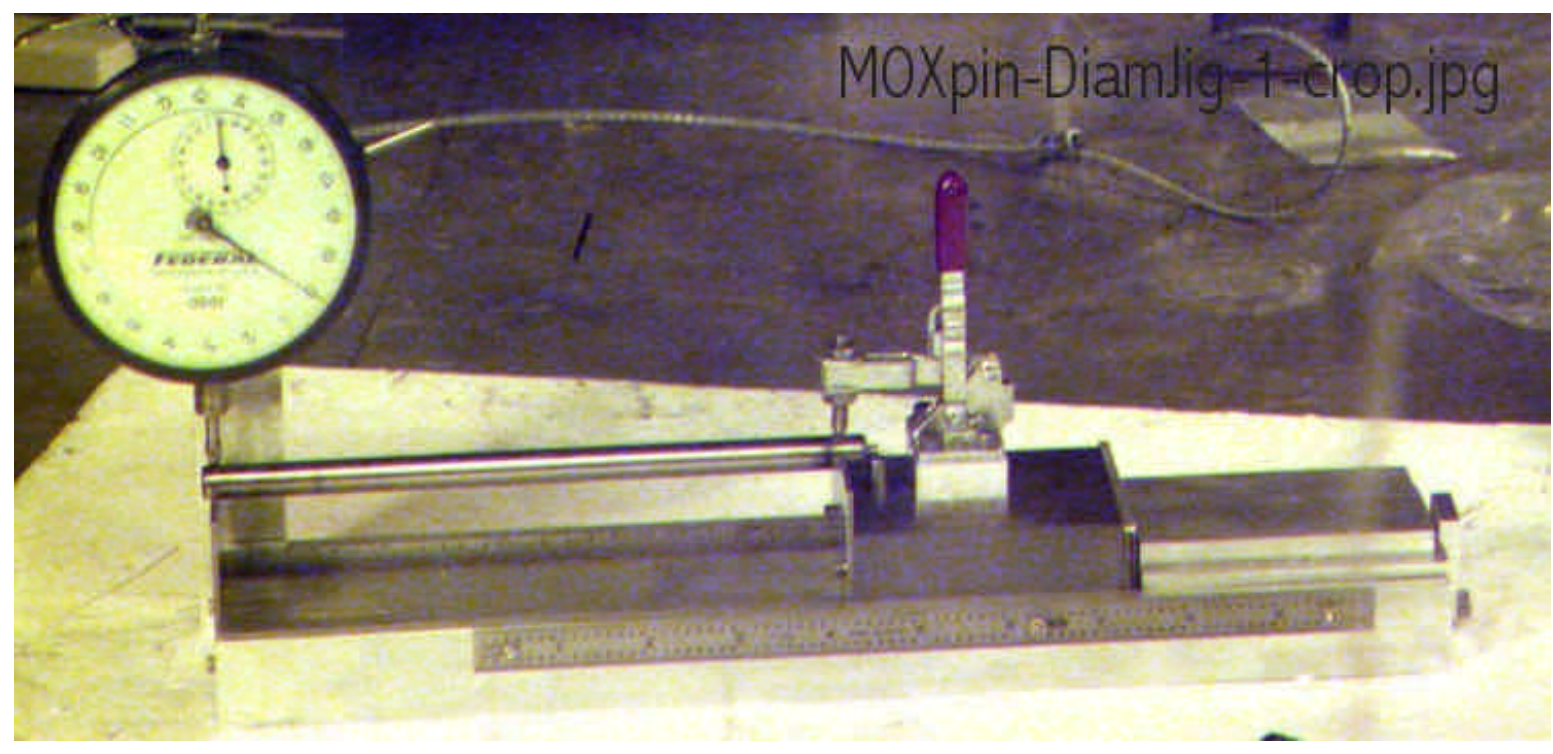

Figure 3.25. Fuel pin measuring jig with Fuel Pin 6 in place.

The results of the Fuel Pin 6 dimensional inspections are shown in Figure 3.27. Diameters are indicated over 5.25 inches of the pellet stack, from 1.00 to 6.25 inches from the zero reference shown in Figure 3.23. Accuracy is estimated to be \pm 0.2 mil. The same inspection for Fuel Pin 13 is shown in Figure 3.28.

There is no evidence of pellet-clad contact and the measured profile is typical of irradiated clad. A slight increase from the preirradiation diameter is evident for both pins. This was expected and is attributed to irradiation growth and primary creep of the clad. Any out-of-roundness, bowing (by the fact that the fuel pins could be removed from the tight fitting capsule), and bambooing are insignificant.

Other Fuel Pin 6 and 13 measurements are recorded in Table 3.6.

Table 3.6. Fuel Pin 6 and 13 Length and Weight

\begin{tabular}{|l|c|r|r|r|}
\hline Fuel Pin & $\begin{array}{c}\text { Length (in) Less } \\
\text { Pedestal } \\
\text { Segment } \\
\pm \mathbf{0 . 0 0 5}\end{array}$ & $\begin{array}{c}\text { Preirradiation } \\
\text { Length (in) Less } \\
\text { Pedestal } \\
\text { Segment }\end{array}$ & $\begin{array}{c}\text { Mass (g) Less } \\
\text { Pedestal } \\
\text { Segment }\end{array}$ & $\begin{array}{c}\text { Preirradiation } \\
\text { Mass (g) Less } \\
\text { Pedestal } \\
\text { Segment }\end{array}$ \\
\hline Fuel Pin 6 & 7.413 & 7.41 & 109.9 & Not given \\
\hline Fuel Pin 13 & 7.415 & 7.41 & 111.8 & Not given \\
\hline
\end{tabular}



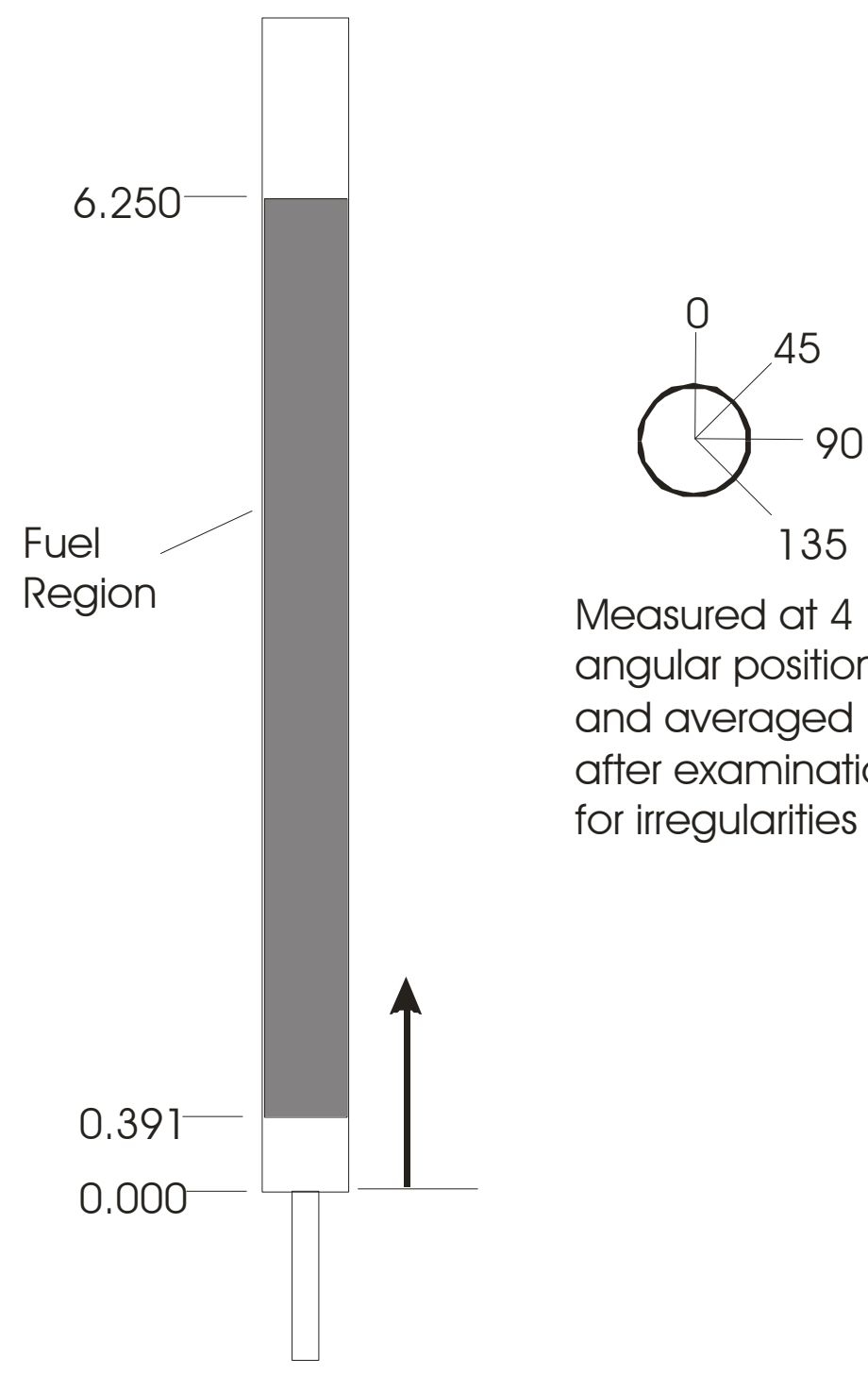

Measured at 4 angular positions and averaged after examination for irregularities

Simple Measure Diagram.cor/emf

Figure 3.26. Fuel pin measurement references. 


\section{Fuel Pin 6 Averaged Diameter Measurement (Simple Jig)}

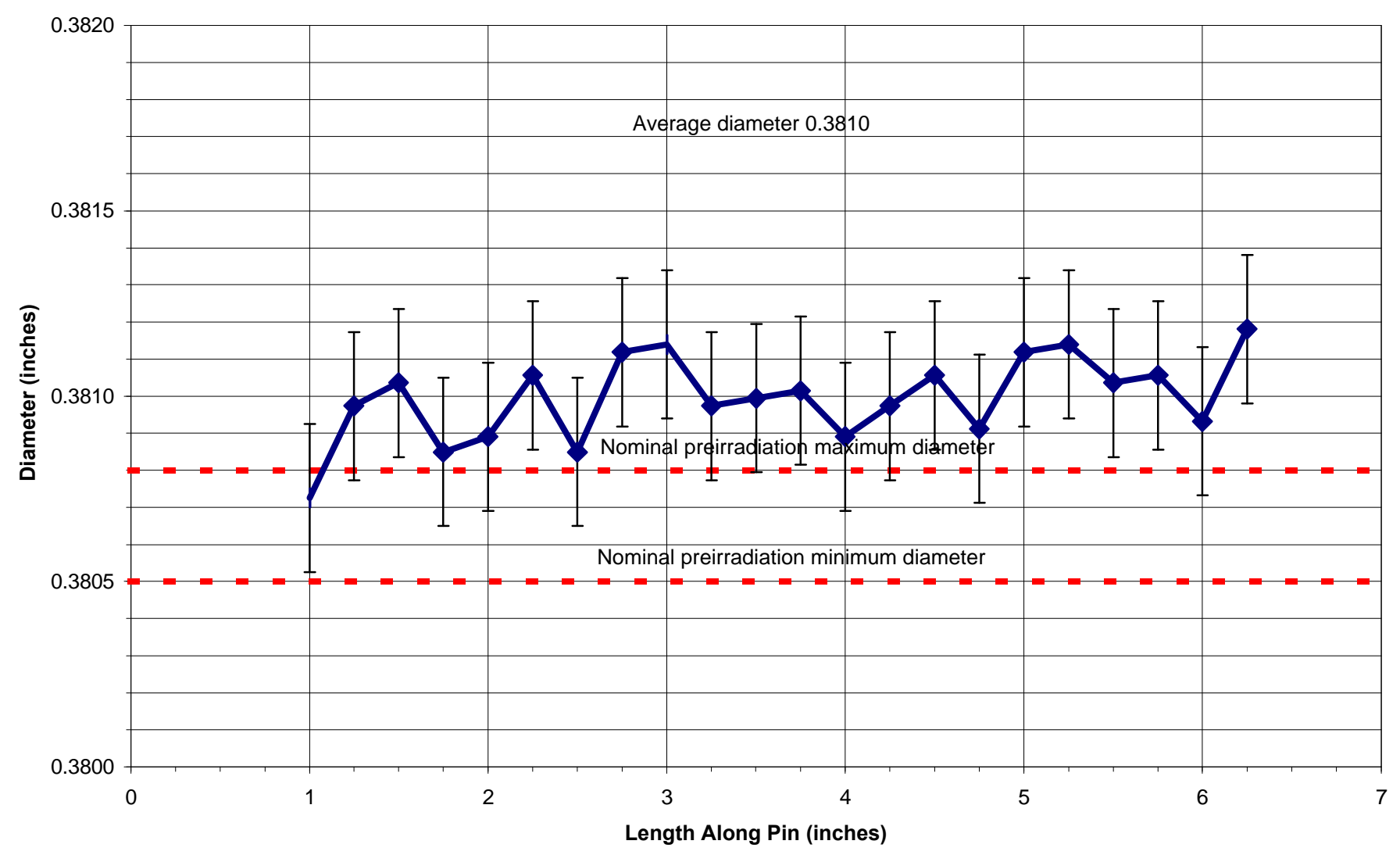

Figure 3.27. Graph of Fuel Pin 6 diametrical measurements. 
Fuel Pin 13 Averaged Diameter Measurement (Simple Jig)

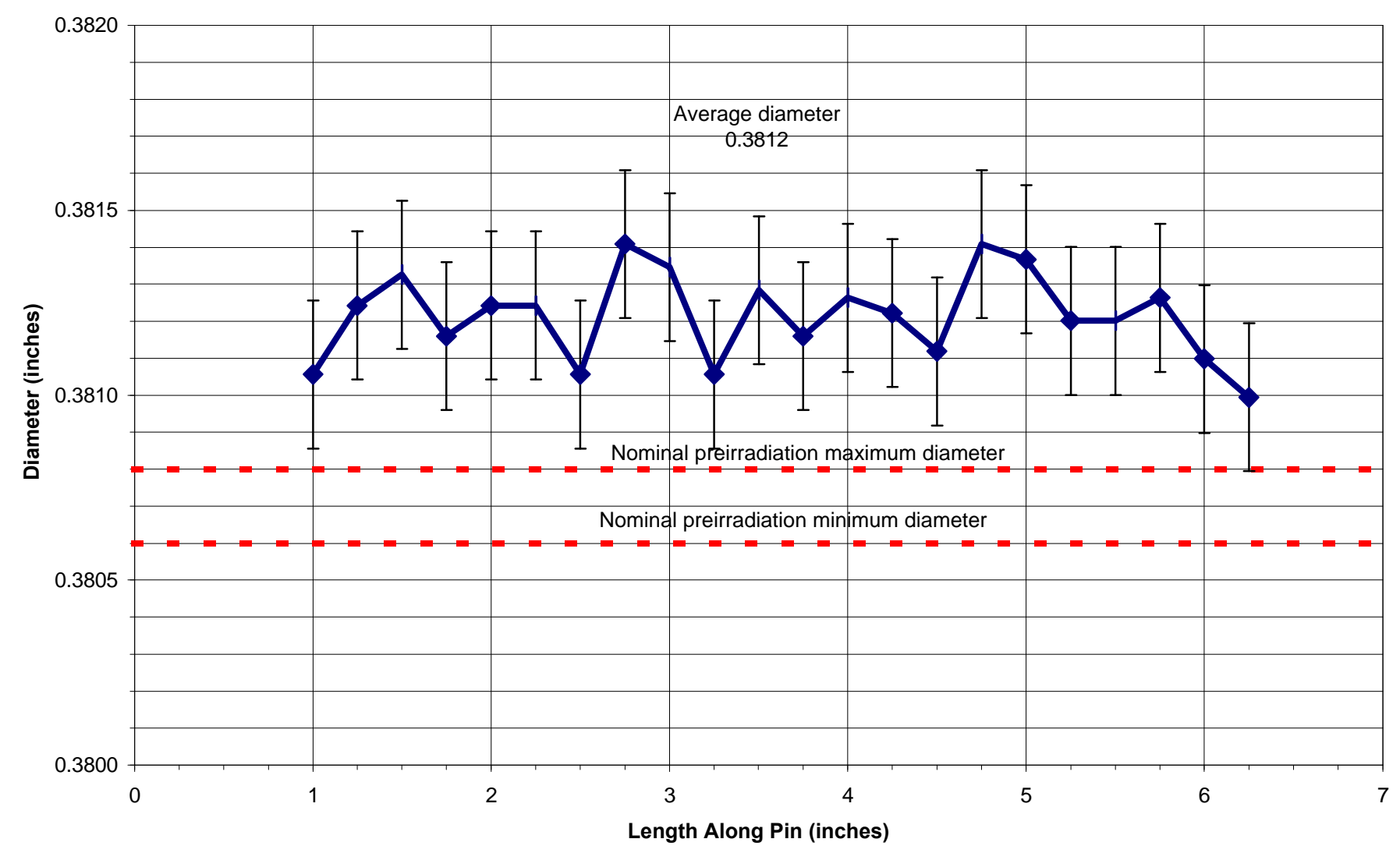

Figure 3.28. Graph of Fuel Pin 13 diametrical measurements. 


\subsection{CONCLUSIONS FROM QUICK LOOK PIE}

Capsules 3 and 10 were visually and dimensionally examined. No signs of capsule damage or distortion were observed. Both capsules were gamma scanned and showed no signs of structural irregularities.

After a sufficient period of time was allowed for the required ${ }^{131}$ I decay, the capsules were drilled to sample their gas plenums and the free volumes in their associated fuel pins. The gas measurements were in the expected pressure range and the implied fission gas release fractions were in the range of 1.5 to $2.26 \%$.

The capsules were opened and the fuel pins removed. No signs of damage or distortion of the fuel pin clad were observed. In fact, the fuel pins slid out as indicated by the CARTS code calculations. Measurements of the fuel pin clad outer diameter showed no signs that pellet-clad contact had occurred during the irradiation, which confirms the fuel behavior predictions. The measured diameters do indicate a slight outward irradiation growth or creep of the clad, as expected.

Overall, this Quick Look suggests that Capsule 3 and Capsule 10 have handled their irradiations without incident. There are no indications of any mechanisms that might threaten the containment integrity of the sister capsules currently continuing their irradiation in the ATR.

When compared to the previous $21 \mathrm{GWd} / \mathrm{MT}$ PIE, a hint of difference between the treated and untreated fuel seems to be developing in fission gas release behavior. Table 3.7 sums up the fission gas releases recorded to date; note that the treated fuel appears to have a slightly higher release at both burnups. Future PIE data will be necessary to determine if this apparent release differential is real.

Table 3.7. Fission Gas Release Data

\begin{tabular}{|l|l|r|l|r|}
\hline \multirow{2}{*}{ Burnup } & \multicolumn{2}{|c|}{ Untreated Fuel } & \multicolumn{2}{c|}{ TIGR Treated Fuel } \\
\cline { 2 - 5 } & \multicolumn{1}{|c|}{ Number } & Release & Number & Release \\
\hline \hline $21 \mathrm{GWd} / \mathrm{MT}$ & Pin 5 & $1.44 \%$ & Pin 12 & $1.95 \%$ \\
\hline $30 \mathrm{GWd} / \mathrm{MT}$ & Pin 6 & $1.50 \%$ & Pin 13 & $2.26 \%$ \\
\hline
\end{tabular}




\subsection{ACKNOWLEDGMENTS}

The authors wish to thank Steve Childs, Charlie DeVore, Pat Howard, Tom Kenney, and Jeff Moody of the Irradiated Fuels Examination Laboratory Staff for their help with the MOX capsule PIE task. We also wish to thank Larry Ott for modeling support. 


\subsection{REFERENCES}

1. B.S. Cowell and S.A. Hodge, Fissile Materials Disposition Program Light-Water Reactor Mixed Oxide Fuel Irradiation Test Project Plan, ORNL/TM-13419, Rev 2, May 2000.

2. R.N. Morris, C.A. Baldwin, C.M. Malone, N.H. Packan, MOX Average Power Early PIE: 8 GWd/MT Quick Look, ORNL/MD/LTR-163 Rev. 1, February 1999

3. R.N. Morris, et. al., MOX Average Power Early PIE: $8 \mathrm{GWd} / \mathrm{MT}$ Final Report, ORNL/MD/LTR-172, November 1999

4. R.N. Morris, et. al., MOX Average Power Intermediate PIE: 21 GWd/MT Quick Look, ORNL/MD/LTR-185, March 2000

5. R.N. Morris, et. al., MOX Average Power Intermediate PIE: 21 GWd/MT Final Report, ORNL/MD/LTR-199, December 2000

6. R.N. Morris, Post-Irradiation Examination Plan for ATR MOX Capsules Withdrawn at $30 \mathrm{GWd} / \mathrm{MT}$ and Higher, ORNL/MD/LTR-195 Rev 0, September 2000

7. S.A. Hodge, Fission Gas Release and Pellet Swelling Within the Capsule Assembly During Phase IV of the Average Power Test Rev 0, ORNL/MD/LTR-184, July 2000

8. R.N. Morris, C.A. Baldwin, C.M. Malone, MOX Fission Gas Pressure Measuring Apparatus, ORNL/MD/LTR-176, January 2000

9. W.T. Terry, As-Run Radiological Characterization of MOX Fuel Capsules Removed from the ATR After Cycle 122C, INEEL Letter WKT-02-00, August 15, 2000 


\subsection{DISTRIBUTION}

1. P.T. Rhoads, U.S. Department of Energy, MD-3, 1000 Independence Avenue SW, Forrestal Building 6G-050, Washington DC 20585

2. J. Thompson, U.S. Department of Energy, MD-3, 1000 Independence Avenue SW, Forrestal Building 6G-050, Washington DC 20585

3-7. D. Alberstein, Los Alamos National Laboratory, P.O. Box 1663, Los Alamos, NM 87545

8-12. R.C. Pedersen, Idaho National Engineering and Environmental Laboratory, EROB, 2525 Fremont Avenue, Idaho Falls, ID 83415-3419

13. P. Kasik, MPR Associates Inc., 320 King Street, Alexandria, VA 22314-3238

14. C.A. Baldwin

15. B.S. Cowell

16. S.R. Greene

17-21. S.A. Hodge

22. L.L. Horton

23. M.W. Kennard, Stoller Nuclear Fuel, 485 Washington Avenue, Pleasantville, NY 10570

24.-28. L.L. Losh, Framatome Cogema Fuels, 3315 Old Forest Road, Lynchburg, Va 24506

29.-33. R.N. Morris

34. L.J. Ott

35. D.J. Spellman

36. K.R. Thoms

37. ORNL Laboratory Records (RC) 